tion, decision making, effective use of groups, supervisory leadership, performance appraisal, and communication. Fee: $\$ 325$. Contact: ARL/OMS, 1527 New Hampshire Ave., N.W., Washington, DC 20036; (202) 232-8656.

23-25-Higher education: "American Dreams: The National Debate about the Future of Education," a symposium hosted by the Indiana University of Pennsylvania, Indiana, Penna. The program will combine presentation and debate. Speakers and debaters include Phyllis Schlafly (Eagle Forum), Eleanor Smeal (NOW), Chester Finn (Department of Education), Mary Hatwood Futrell (NEA), and Stanley Aronowitz (CUNY). Contact: American Dreams, Department of Sociology-Anthropology, IUP, Indiana, PA 15705; (412) 357-2730, 357-2227.

24-Reference service: "Are We Getting Where We Are Going? Evaluating Reference Services," a workshop conducted by Charles A. Bunge of the University of Wisconsin Library School, will be held at the University of Texas, Thompson Conference Center, Austin. Fee: \$35. Contact: Mel Boggins, Director of Placement and Continuing Education, Graduate School of Library and Information Sciences, University of Texas, Austin, TX 78712-1276; (512) 471-3821.

30-November 1-South Carolina: South Carolina Library Association Annual Convention, Radisson Hotel, Columbia. Contact: Susan Hollifield, University of South Carolina Library, 171 University Parkway, Aiken, SC 29801; (803) 2298367.

30-November 2-Africana: Fall Meeting, Archives-Libraries Committee of the African Studies Association, Madison, Wisconsin. A meeting of the Cooperative Africana Microforms Project is also planned. Contact: D.M. Hull, Chair, Moorland Springarn Research Center, Howard University, Washington, DC 20059; (202) 636-7260.

\section{November}

6-7-Technical services: "Formats: Old and New," the Online Audiovisual Catalogers Conference '86, hosted by OCLC, Dublin, Ohio. Shirley Lewis (Information Services) and Donald Bidd (National Film Board of Canada) will be keynote speakers. Fee: $\$ 25$ for OLAC members and OCLC user group school librarians, \$35 for non-members. Contact: Barbara Ritchie, Project Manager-LS/2000, OCLC, Inc., 6565 Frantz Road, Dublin, OH 430170702 .

6-9-Ontario: "Excellence and Leadership: The Challenge," 84th Annual Conference, Ontario Library Association, Royal York Hotel, Toronto. Contact: OLA, 73 Richmond Street West, Suite 402, Toronto, Ontario M5H 1 Z4.

12-Gillard Lecture: 17th Annual William A. Gillard Lecture, St. John's University Council Hall, Jamaica, New York. Lecturer will be John N.
Berry III, editor-in-chief of the Library Journal. Contact: Mildred Lowe, Division of Library and Information Science, St. John's University, Jamaica, NY 11439; (718) 990-6200.

18-21-Management: Basic Management Skills Institute, sponsored by ARL's Office of Management Studies, held in Scottsdale, Arizona. See October 14-17 entry.

\section{December}

1-4-Management: Library Analytical Skills Institute, sponsored by ARL's Office of Management Studies, to be held in Baton Rouge, Louisiana. Topics covered include the problem-solving process, data gathering and analysis, creativity and analytical thought, strategy formulation, presentation, and implementation. Fee: $\$ 450$. Contact: ARL/OMS, 1527 New Hampshire Ave., N.W., Washington, DC 20036; (202) 232 8656.

\section{January}

8-9-Archives: Advanced Records Management, a course offered by the Continuing Engineering Education Program of George Washington University. The course covers principles of file organization, indexing, and electronic storage. Instructor: William Saffady. Fee: $\$ 650$. Contact: Darold Aldridge, Continuing Engineering Education, George Washington University, Washington, DC 20052; (800) 424-9773 or (202) 6768522 .

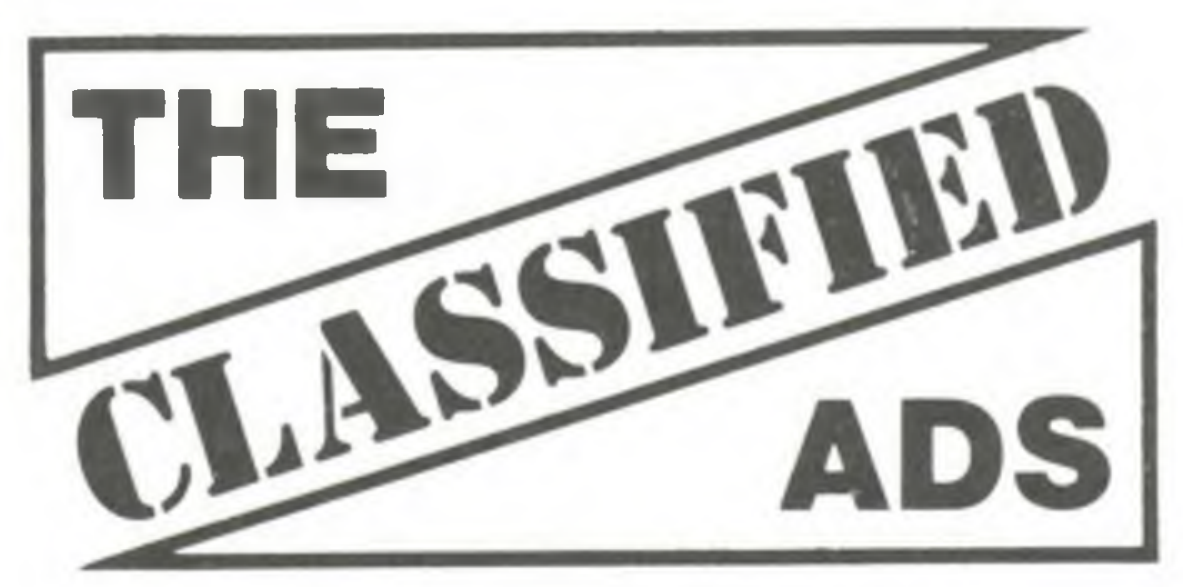

Deadlines: Orders for regular classified advertisements must reach the ACRL office on or before the second of the month preceding publication of the issue (e.g. September 2 for the October issue). Late job listings will be accepted on a space-available basis after the second of the month.

Rates: Classified advertisements are $\$ 5.00$ per line for ACRL members, $\$ 6.25$ for others. Late job notices are $\$ 12.00$ per line for members, $\$ 14.00$ for others. Organizations submitting ads will be charged according to their membership status.

Telephone: All telephone orders should be confirmed by a written order mailed to $A C R L$ headquarters as soon as possible. Orders should be accompanied by a typewritten copy of the ad to be used in proofreading. An additional $\$ 10$ will be charged for ads taken over the phone (except late job notices or display ads)

Guidelines: For ads which list an application deadline, that date must be no sooner than the 20th day of the month in which the notice appears (e.g., October 20 for the October issue). All job announcements should include a salary figure. Job announcements will be edited to exclude discriminatory references. Applicants should be aware that the terms faculty rank and status vary in meaning among institutions.

JOBLINE: Call (312) 944-6795 for late-breaking job ads for academic and research library positions. A pre-recorded summary of positions listed with the service is revised weekly; each Friday a new tape includes all ads received by 1:00 p.m. the previous day. Each listing submitted will be carried on the recording for two weeks. The charge for each two-week listing is $\$ 30$ for ACRL members and \$35 for non-members. 
Fast Job Listing Service: A special newsletter for those actively seeking positions. This service lists job postings received at ACRL headquarters four weeks before they appear in C\&RL News, as well as ads which, because of narrow deadlines, will not appear in C\&RL News. The cost of a six-month subscription is $\$ 10$ for ACRL members and $\$ 15$ for non-members.

Contact: Classified Advertising Dep't, ACRL, American Library Association, 50 E. Huron St., Chicago, IL 60611; (312) 944-6780.

\section{FOR SALE}

NEW YORK TIMES, January 1977-May 1986 inclusive, 275 reels on negative microfilm. New, $\$ 10,960$. Asking $\$ 5,500$ or best offer Call or write Richard Peplow, Schiff Hardin \& Waite, 7200 Sears Tower, Chicago, IL 60606; (312) 876-1000.

\section{WANTED}

USED 60 or 72 drawer card catalog. Call or write Frank Baudonnet Shields Library, University of California-Davis, Davis, CA 95616 (916) $752-2110$.

\section{POSITIONS OPEN}

ARCHITECTURE LIBRARIAN. Assistant Professor (tenure leading). Humanities \& Social Sciences Department, starting January 1,1987 . Under the general direction of the Chair of the Humanities \& Social Sciences Department, this position will 1) assume administrative and supervisory responsibilities for Architecture Library, including Slide Collection; 2) provide information and reference assistance to university and non-university users; 3) provide li- brary instruction; 4) promote and perform computerized literature searches; 5) assess and develop Architecture and Community and Regional Planning collections; 6) work with book chairs and other faculty in Departments of Architecture and Community and Regional Planning on library related matters; 7) participate in committee, faculty, departmental, and professional meetings, conferences, work shops, etc. Required: MLS from an ALA-accredited library school; two years of professional academic library experience; and ability to relate well to patrons and staff. Preferred: degree in architecture, planning, or art history; experience and training in online literature searching; good working knowledge of one or more Western European languages (German or French or Italian are the most useful); and supervisory experience. $\$ 19,000$ minimum for a twelve-month contract. Salary may be higher depending upon the qualifications of the successful applicant. Apply with full resume plus names and current addresses/telephone numbers of three references by October 15, 1986, to: Kent Hendrickson, Dean of Libraries, 106 Love Library University of Nebraska-Lincoln, Lincoln, NE 68588-0410. Affirmative Action, Equal Opportunity Employer.

ASSISTANT DIRECTOR FOR ACCESS SERVICES. Reports to the Director of Libraries and is responsible for the administration, planning and policy direction of Access Services comprising the Monographs, Serials and Circulation Divisions, with 8 professional staff; 22.5 classified staff and 22 student staff FTE. Responsibilities: Directs the Access Services staff in the acquisition, bibliographic control and organization, physical processing and circulation of library materials; manages and develops the library's automated sys tems including liaison with CSU Computer Services and OHIONET/ OCLC; participates in library-wide planning and policy formulation. Requirements: ALA-accredited MLS; minumum 7 years professional experience in bibliographic control; knowledge of and experience with library automated systems, including OCLC or other bibliographic utilities; knowledge of acquisitions, circulation operations and budgeting. Desirable: Knowledge of at least one foreign language; second master's degree. Salary: $\$ 30,000-\$ 35,000+$ depending on experience and qualifications. Send resume and names of 3 current references by October 10, 1986, to: Brian Ruddick Chair, Search Committee, Assistant Director of Libraries for Access Services, Cleveland State University, 1983 E. 24th St., Cleveland, $\mathrm{OH}$ 44115. EOE, $\mathrm{m} / \mathrm{f} / \mathrm{h}$

ASSISTANT OR ASSOCIATE UNIVERSITY LIBRARIAN, TECHNICAL SERVICES, The University Library, University of California

\%

\section{ASSOCIATE DIRECTOR FOR SYSTEMS AND ACCESS SERVICES \\ DePaul University}

Will report to the Director of Libraries and be responsible for investigating computer technologies and their library applications with the goal of implementing an integrated online system linked with national and regional networks. Will conduct a review of current automated systems including OCLC and LCS, and will provide leadership in planning for an online catalog and the continued automation of the circulation, serials, and acquisitions functions. Will plan and implement further use of microcomputers for library functions and programs. This position will have supervisory responsibility for the acquisitions, cataloging, circulation, and serials departments. Will serve as a subject bibliographer for one or more subjects.

DePaul University has an enrollment of nearly 13,000 students of whom 4,000 are in graduate or professional programs. The libraries are on the 2 main campuses as well as one auxiliary campus, all of which are located in the Chicago metropolitan area. The libraries have a combined collection of 275,000 volumes, 17,000 microform volumes, and 2,600 current periodical subscriptions.

Qualifications: ALA-accredited MLS required. Additional subject master's preferred. Minimum 5 years increasing responsibility in library position with some supervisory experience. Demonstrated knowledge of library systems and technical services and familiarity with academic library service. Excellent written and oral communication skills. Evidence of continued professional growth. Good interpersonal skills. Liberal fringe benefits: TIAA/CREF, salary mid- $\$ 30$ 's, good hospitalization and more. Send letter of application and resume by September 30, 1986, to: Doris Brown, Director of Libraries, DePaul University, 2323 N. Seminary Ave., Chicago, IL 60614. 
San Diego. Salary range: $\$ 38,600-\$ 63,200$. Available November 1 1986. Under the general direction of the University Librarian, re sponsible for administering four departments-Acquisitions, Catalog, Documents, and Systems-and for coordinating technical services operations throughout the Library. The AUL is a member of the Library's administrative team and participates in planning and decision-making with respect to overall policies and operations. The incumbent represents the UCSD Library on campus, on UC systemwide committees, and in other arenas, as appropriate. The AUL contributes to the profession and maintains an awareness of current professional organizations and activities. Qualifications: An understanding of the scholarly use of library collections and services; an awareness of trends in higher education and library services; demonstrated ability to work effectively with library staff and other members of a research-oriented academic community; considerable academic library experience, including a comprehensive knowledge of technical service operations and a strong working knowledge of automated technologies and their potential for increased application in academic libraries; the ability to provide leadership in dynamic and rapidly changing circumstances; a commitment to the overall goal of public service and an appreciation of the importance of interaction between public and technical service operations in improving and extending the library's information services. MLS from an ALAaccredited library school is required. Knowledge of research and evaluation techniques is highly desirable. UCSD is an equal opportunity, affirmative action employer. Applications received or postmarked by October 15,1986, are assured of consideration. Submit a letter of application, enclosing a resume and a list of references to: Dorothy Gregor, University Librarian, Library, C-075-G2, University of California, San Diego, La Jolla, CA 92093

ASSISTANT REFERENCE LIBRARIAN (Science \& Technology Library), North Texas State University Libraries, Denton, Texas. Position description: The Assistant Reference Librarian provides reference services to students, faculty, and other patrons of the collection in the University Libraries under the direct supervision of the Library \& Information Sciences Librarian. This position involves a variety of bibliographic and consultative duties including library instruction and database searching. Minimum qualifications: This position requires an MLS from an ALA-accredited library school and two or more years experience in the reference component of an academic, special, or large public library. A combination of supervisory experi- ence, reference desk experience, good communication and interpersonal skills, teaching experience and enthusiasm for library instruction is being sought. Some experience with collection development would be desirable. A subject speciality in the pure sciences. Desirable qualifications: A second master's degree in chemistry or biology, and a foreign language. Available: Immediately. Sal ary: $\$ 18,168$ + depending upon qualifications. Applicants should send a resume, copies of all transcripts, and the names and ad dresses of three references to: Margaret E. Galloway, Associate Director of Libraries, North Texas State University, Box 5188 N.T. Station, Denton, TX 76203-5188. Applications will be accepted unti position is filled. Applications received before November 1, 1986 have a better chance of being hired. North Texas State University is an equal opportunity, affirmative action employer

ASSISTANT REFERENCE LIBRARIAN (Search re-opened.) James Madison University's Carrier Library is seeking an Assistant Reference Librarian. The University is a publicly supported institution offering primarily undergraduate programs (enrollment approximately 9,400 FTE). There are also graduate programs at the master's level. Located in Virginia's Shenandoah Valley, the University is considered one of the outstanding regional schools and aspires to be one of the best public undergraduate institutions in the nation Carrier Library's facilities are modern (new addition and renovation in 1982), contain over 600,000 items in the collections, offer media resources services, and have installed the VTLS online catalog and circulation system. The staff consists of 17 library faculty and approximately 34 FTE classified staff. The Assistant Reference Librarian is a faculty position with rank, is tenure-track and a 12 month appointment. Benefits include 20 days vacation plus University holidays paid BC/BS health insurance. Retirement options are State or TIAA/ CREF with the University making full contribution. Salary range is $\$ 20,000-\$ 22,000$ depending on experience and qualifications. Position Description: The Assistant Reference Librarian provides general reference assistance, serving at the Reference Desk during as signed times including one evening per week and rotating weekends; performs online database searching; participates in the development of the Reference collection and general collection, and serves as faculty liaison to designated academic departments; participates in formal library instruction and prepares research aids. The position reports to the Head Reference Librarian. Qualifications and Experience: Requires ALA-accredited Masters degree in Library

\section{DIRECTOR OF LIBRARY SERVICES State University of New York College at Fredonia}

The State University of New York College at Fredonia invites applications and nominations for the position of Director of Library Services, effective January 1, 1987, or as soon as possible thereafter. The Director of Library Services reports to the Vice President for Academic Affairs and is responsible for the total mission of the library. The Director administers the library budget and supervises public services, personnel, and technical services including systems development for computerization. The library has a staff of 11 full-time librarians, 16 full-time support staff, and 12 FTE student assistants. Supervision of the Instructional Resources Center with a staff of 11 full-time professionals and three full-time support staff may become a part of the responsibilities of the Director.

The library houses over 360,000 bound volumes of monographs and periodicals including 33,000 volumes of music scores, over 800,000 microform units of government documents, research reports, and periodical backfiles. A new library addition is presently in the planning stage.

Qualifications include master's degree from an ALA-accredited library school. A second master's degree or Ph.D. is desirable. A minimum of six years of library administrative experience in an academic institution is required. Knowledge and understanding of new technological applications of libraries is expected.

Familiarity with the OCLC system and the administration of A/V services is required. Salary range for twelve months is $\$ 40,000-\$ 50,000$ depending on qualifications. Usual New York State management/confidential benefits including, among other things, paid vacation and sick leave, retirement plan, dental and health plans. Applications with references should be sent to: Jack Cogdill, Chairperson, Library Search Committee, 213 Michael C. Rockefeller Arts Center, State University of New York College at Fredonia, Fredonia, New York 14063. Deadline for application is October 1, 1986. Women and minorities are encouraged to apply. 
Science and a good academic record in both undergraduate and graduate studies. Evidence of excellence in skills or performance re lated to the responsibilities of the position. Requires active commitment to librarianship and to public service goals and philosophy; ef fective oral and written communication skills; superior interpersona skills and ability to work well with colleagues. Some reference experience desirable. Application Deadline: Applications for the position should include resume, transcripts, and three letters of reference. Deadline is October 1, 1986. Send to Ralph Alberico, Head Reference Librarian, James Madison University, Harrisonburg, VA 22807. James Madison University is an affirmative action, equal opportunity employer.

ASSISTANT SOCIAL SCIENCES LIBRARIAN with faculty rank Position reopened. Two-year appointment. Serve as a specialist in philosophy, psychology, sociology, and related fields in the Social Sciences Division. Select bibliographic materials in these areas for the Library. Serve at the reference desk, provide library instruction, maintain liaison with subject departments, and perform computer searches. Serve on library committees at the request of the University Librarian. Master's degree from an ALA-accredited library school; bachelor's or master's degree in the social sciences, prefera bly in psychology or sociology. Good fringe benefits; 22 working days vacation and 8 holidays. Salary: $\$ 16,800$. For full consideration applications should be received by October 15, 1986. Submit letter of application with resume including names of three references to: Roscoe Rouse, University Librarian, Oklahoma State University, Stillwater, OK 74078. AA/EO Employer.
ASSOCIATE UNIVERSITY LIBRARIAN FOR TECHNICAL AND AUTOMATED SERVICES. Available: On or about January 1, 1987 Reporting to University Librarian, the Associate University Librarian for Technical and Automated Services administers, coordinates, provides leadership for acquisitions, cataloging, and automation functions of Rutgers University libraries. Primary goals for near future are planning for implementation of an integrated online library system, construction of a new technical services facility and library computer center. Has line responsibility for central cataloging, acquisitions departments and library automation office, which currently employ 83 FTE (16 are classified as faculty/managerial and 67 as support staff) in addition to substantial number of student assistants. Coordinates, provides leadership for technical services in $23 \mathrm{li}$ braries on three campuses. Participates in systemwide administrative processes including long-range planning, budgeting, resource allocation, staff development, personnel decisions, and formulating library goals and policies. MLS from ALA-accredited library schoo required; substantial managerial and administrative experience, in research library, with emphasis on technical services; knowledge of and experience with library automation; demonstrated success in written and oral communication and analytical, budgeting, planning activities; knowledge and understanding of research library organizations, sound grasp of issues and trends facing research libraries record of demonstrated leadership in issues of bibliographic access preferably in large research library; proven leadership ability locally and in profession. Candidate's credentials, level of achievement should warrant appointment and tenure in library faculty. Minimum appointment salary in the 50's, depending upon experience and

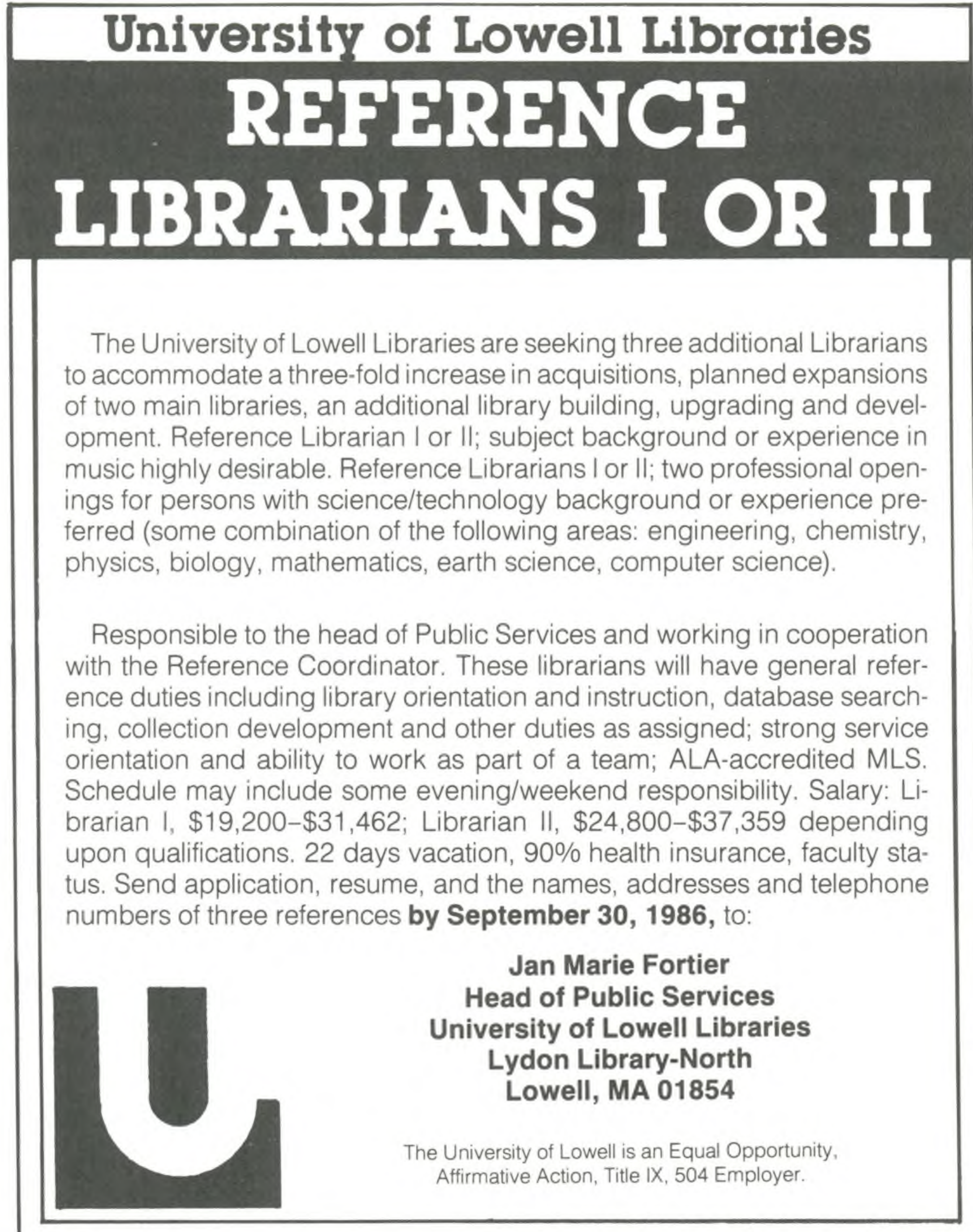


qualifications. Faculty status calendar year appointment, TIAA/ CREF, life/health insurance, 22 days vacation per full contract year, tuition remission, prescription drug/dental/eyeglass reimbursement plans. Applications received by August 15, 1986 will receive first consideration. Submit cover letter, resume, and list of five references knowledgeable of applicant's qualifications and experience to: Barbara E. Sanders-Harris, (APP 117), Personnel Officer, Alexander Library, Rutgers University, New Brunswick, NJ 08903. An equal opportunity, affirmative action employer

CATALOG LIBRARIAN. Responsible for original and complex copy cataloging of monographic materials and all cataloging of audiovisual materials. This is a 12 month fixed term faculty position and reports to the Coordinator of Technical Services. Joyner Library is a LS/2000 installation that serves 14,000 students and 750 faculty members. East Carolina University, with eight professional schools a College of Arts and Sciences, and extensive off-campus degree programs offered through the Division of Continuing Education, is part of the 16-campus University of North Carolina System. Qualifications required: ALA-accredited MLS degree; working knowledge of AACR2, LCSH, LC classification, and OCLC standards; and good communication skills. Experience with audiovisual cataloging knowledge of a modern European language, and ability to work well independently are preferred. A second masters degree is desirable. Minimum salary $\$ 20,000$. Position available January 1,1987 . Send letter of application, resume, official transcripts, and names of three current references to: Ruth M. Katz, Director of Academic Library Services, Joyner Library, East Carolina University, Greenville, NC 27834-4353. Applications must be postmarked on or before October 31, 1986. East Carolina is an AA/EEO employer

CATALOGER. Responsible for original and copy cataloging of monographs and serials using AACR2, Library of Congress classification, and LC subject headings. All cataloging is done via the OCLC system and the library is in the planning phase of a project to acquire a comprehensive local automated system. Responsibilities include the cataloging of rare items and Arkansas-related materials. ALA-accredited MLS required. Working knowledge of a foreign language and interest in library automation desirable. Salary and rank dependent on qualifications and experience, $\$ 17,500$ minimum. Twelve-month, tenure-track, TIAA/CREF, 22 days annual leave, many other fringe benefits. Position available November 1. Applications accepted until suitable candidate is found. As the major academic research institution in the state, the University of Arkansas,
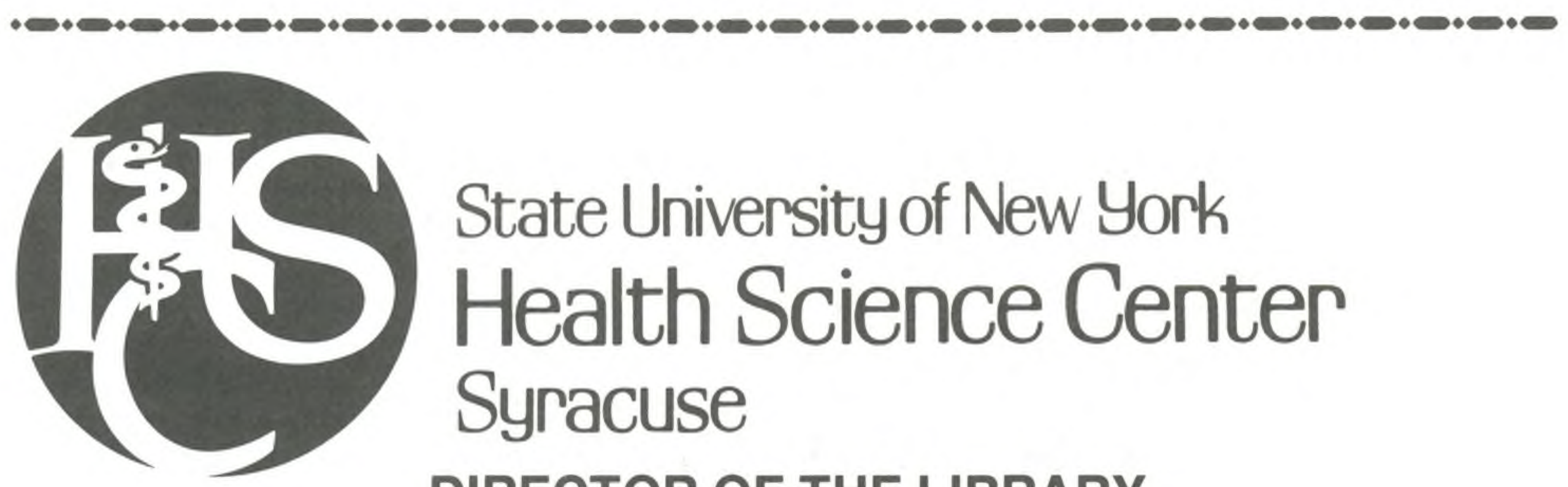

\title{
State University of New York
} Health Science Center Syracuse

\section{DIRECTOR OF THE LIBRARY}

SUNY Health Science Center at Syracuse (formerly Upstate Medical Center) invites applications for the position of Director, Health Sciences Library. The Library supports the educational, research and informational needs of Health Science Center faculty and students of the Colleges of Medicine, Health Related Professions, Graduate Studies, Nursing and the University Hospital. The Library serves approximately 6,000 users annually with a collection of over 145,000 volumes, a budget of $\$ 864,000$ and a staff of 21 .

The Director is responsible for the administration and development of the Health Sciences Library, including collection and resource development, planning, fiscal management, user and technical services, automation and staff supervision. The Director reports to the Provost of the Health Science Center.

Required qualifications include:

-MLS from ALA-accredited program;

- professional experience in a Health Sciences setting;

- considerable experience in a managerial/supervisory capacity with increasing

progression of responsibility;

-experience in information systems;

- demonstrated participative managerial skills, including communication skills;

-budgetary and fiscal management and development skills;

- record of active participation in professional library associations;

-commitment to research in Health Sciences and Information Technology.

Salary commensurate with qualifications and experience (minimum salary $\$ 52,000$ ); excellent fringe benefits. Position is at Librarian rank in State University of New York system.

Send letter, resume with salary requirements and name, address and phone number of references by October 17, 1986, to:

\author{
Donald C. Goodman \\ Provost and Chair, Library Director Search Committee \\ 1101 Silverman Hall \\ SUNY Health Science Center \\ Syracuse, NY 13210
}


Fayetteville, a land-grant university, offers a full range of undergraduate, graduate, and professional degrees. Located in scenic Northwest Arkansas, Fayetteville is a university town of 40,000 in a picturesque setting in the foothills of the Ozarks, an unspoiled region with clean air, a temperate climate, and a variety of cultural and recreational opportunities. Letter of application and resume of education and experience and the names of three references should be submitted to: John A. Harrison, Director, University Libraries, University of Arkansas, Fayetteville, AR 72701. The University of Arkansas is an Equal Opportunity, Affirmative Action Employer

CATALOGER, Librarian II. Responsible for original cataloging of monographs and AV materials. May also participate in weekend reference desk rotation, collection development, library instruction, and other duties as assigned. Reports to Head of Catalog Department. Requires MLS from ALA-accredited program; thorough knowledge of AACR2, LCSH, MARC formats; 2 or more years of cataloging experience. Experience in AV cataloging and with OCLC and working knowledge of German language is desirable. North Dakota State University is a land grant university serving over 9.500 students, a member of Tri-College University (NDSU, Moorhead State University, and Concordia College), and a participant in Minnesota State University System's PALS online catalog. Benefits include TIAA/CREF, Blue Cross/Blue Shield, \$19,524 minimum salary. Position available immediately. Application deadiine October 15, 1986. Submit application, resume, and 3 current letters of reference to: Personnel Office, North Dakota State University, P.O. Box 5277 , Fargo, ND 58105. North Dakota State University is an equal opportunity institution

CATALOGER, Technical Services Division. Position is currently vacant. Responsible for cataloging of monographic materials, including specialized and non-book materials. Descriptive and subject cataloging and Library of Congress classification, using most current AACR rules. Formatting and MARC tagging copy for input into West- ern Library Network. A progressive record of professional scholarly achievement is expected of all librarians. Required: ALA-accredited $M L S$ required. Preferred: Experience in monographic cataloging in a variety of subject areas using Library of Congress classification and subject headings; and AACR2, preferably in an academic library; the ability to work with foreign languages commonly encountered in academic libraries, including transliteration of Cyrillic materials; the ability to catalog non-print and specialized material; expertise in use of MARC tagging, library networking and bibliographic utilities, preferably WLN. Rank and salary commensurate with experience and qualifications. TIAA/CREF, broad insurance program. Send letter of application, resume and names of three references to: Donna L. McCool, Assistant Directer for Administrative Services, Libraries, Washington State University, Pullman, WA 99164-5610. Review of applications begins October 31, 1986. Washington State University is an equal opportunity, affirmative action employer.

CHAIRPERSON, HUMANITIES \& SOCIAL SCIENCES DEPARTMENT, starting January 1, 1987. General Description: Administer all activities of the Humanities \& Social Sciences Department, including collection development, reference/information service, library instruction, and two branch libraries (Architecture and Music). Specific duties include: overall supervision of twelve librarians and seven support staff; coordination of collection assessment and collection development within the department; preparation and monitoring of personnel, materials and equipment budgets; establishment of de partment goals and objectives; and participation on management level committees. Required: MLS from an ALA-accredited library school, a minimum of five years professional library experience in a public service division of an academic library; and excellent communication skills and organizational abilities. Preferred: an advanced degree in a humanities or social sciences discipline; online literature searching experience; familiarity with current developments in library instruction; collection development experience; and 2-3 years of supervisory/managerial experience. $\$ 30,000$ minimum

\section{ACCESS SERVICE LIBRARIAN Purdy/Kresge Library, Wayne State University}

This is a librarian position with system-wide responsibility for an automated circulation system. Included in this assignment is supervisory responsibility for the Purdy/Kresge Circulation Desk staff and the Purdy/ Kresge Interlibrary Loan Service. Specific assignments will include development and monitoring of circulation policies and procedures for the University Library system. This position may also include some participation in bibliographic instruction, collection development, faculty liaison and in the reference schedule. This position may lead to tenure based on the standards of evaluation and quality of performance in (a) professional assignments, (b) creative or scholarly work, and (c) contributions to the profession.

Qualifications and desired characteristics: Master's Degree from an ALA-accredited library school is required. Experience with an automated circulation system is preferred. Effective verbal and communication skills are essential. Strong leadership and good interpersonal skills are essential. Reports to the head of the Purdy/Kresge Library.

Other Information: The Purdy/Kresge Library is part of the University Library system which includes the Neef Law Library, the Science and Engineering Library and the Shiffman Medical Library. Purdy/Kresge houses collections in the humanities and social sciences, with primary use by the College of Liberal Arts, College of Education, and the School of Social Work.

Liberal fringe benefits, dental and health plan options, TIAA/CREF, tuition support for family members, minimum salary of $\$ 19,000$ - $\$ 20,000$, rank competitive and negotiable based on experience and qualifications.

Position open immediately and will remain open until filled. Applications received September 30, 1986, will be given first consideration. Applications (including a signed and dated resume) should be sent with three references to:

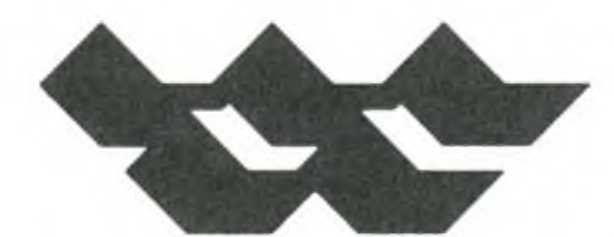

Wayne State University

\author{
James Williams II \\ Associate Director \\ 134 Purdy Library \\ Wayne State University \\ Detroit, MI 48202
}


for a twelve-month contract. Salary may be higher depending upon the qualifications of the successful applicant. Apply with full resume plus names and current addresses/telephone numbers of three references by October 15, 1986, to: Kent Hendrickson, Dean of Libraries, 106 Love Library, University of Nebraska-Lincoln, Lincoln, NE 68588-0410. Affirmative Action, Equal Opportunity Employer

COLLECTION DEVELOPMENT COORDINATOR, Owen Science and Engineering Library. Appointment begins February 1, 1987. Responsible for coordinating collection development. Other duties in clude bibliographic instruction, online searching, reference, collection development/liaison with specific departments. A progressive record of professional scholarly achievement is expected of all librarians. The Owen Science and Engineering Library is a modern 7 story building with a staff of 26, including 8 librarians; contains 400,000 volumes and 611,000 microforms. Library has automated circulation, acquisitions and bibliographic systems. Required: ALA accredited degree. Preferred: Experience in a science/engineering/medical library and/or subject background; collection development coordination; computerized literature searching. Rank and salary commensurate with experience and qualifications. TIAA CREF, broad insurance program. Send letter of application, resume and names of three references to: Donna L. McCool, Assistant Director for Administrative Services, Libraries, Washington State Univer sity, Pullman, WA 99164-5610. Review of applications begins October 15,1986 . Washington State University is an equal opportunity affirmative action employer
COLLECTION DEVELOPMENT COORDINATOR (ReAdvertisement). The Coordinator for Collection Development functions as the chief officer for the development and management of the library's learning materials collection. Responsibilities include: assessing the collection's strengths and weaknesses, maintaining knowledge of the academic missions and programs, maintaining awareness of the production and publication of the academic and professional literature necessary to meet the curricular and research needs of the diverse Auraria programs, planning and implementing programs to develop and maintain a quality collection in support of these programs, allocating funds for collection purchases within individual subjects. Under the general direction of the Assistant Director for Instruction and Research Services, the Coordinator for Collection Development shares supervision of fourteen liaison librarians with the Coordinators for Reference and Bibliographic Instruction librarians. The Coordinator assists and provides leadership to the liaison librarians in determining library needs within subject specialties and building collections to meet these needs. Provides reference at a general reference desk. University of Colorado faculty status responsibilities include professional service and scholarly activities. Qualifications required: An ALA-accredited Master's degree in Library Sci ence and demonstrated successful professional experience in collection development. Desired: Evidence of ability to lead, coordi nate and motivate professional associates within a collegial framework: knowledge of trends and issues in academic library collection development; experience in utilizing data analysis in a creative problem-solving context; effective writing, speaking and interper-

The General Research Division, consisting of the Public Catalog, Main Reading Room and Periodicals sections, is the largest division of The Research Libraries of The New York Public Library. The subject collections cover primarily the humanities and liberal arts, collected on an international basis from both current and historical perspectives. The division is staffed by over 30 FTE professionals, supported by a technical and clerical staff. Annual materials budget FY ' 86 -' 87 is expected to be in excess of $\$ 800,000$. The division has an on-line catalog, RLIN, OCLC and IBM PCs for use in reference service.

Under the general direction of the Associate Director for Public Services, is responsible for the administration of all sections of the General Research Division, for the reference and research and automated services related thereto, and for the administration of all staff. Under the general direction of the Associate Director for Collection Development, is responsible for overall coordination of the selection of materials added to The Research Libraries' collections in selected areas of the humanities.

The successful candidate will have a Master of Library Science degree and substantial library administrative and supervisory experience, including planning, organizing and coordinating the work of staff services, staff development, analyzing and evaluating operations and procedures, collection development and automated systems. Thorough knowledge of and dedication to reference work, extensive subject knowledge in the humanities or liberal arts; relevant subject master's degree preferred. Excellent interpersonal skills and inspiring leadership qualities essential.

Send resume and salary history (before September 15), to: Diane G. Riordan, Human Resources Department. Candidates selected for further consideration will be contacted for an interview.

\section{The New York Public Library}

Fifth Avenue and 42nd Street, New York, NY 10018

An equal opportunity employer $M / F$ 
sonal skills. The Auraria Library occupies a unique position as the central point for information services in support of the programs of three diverse academic institutions on one downtown campus. The University of Colorado-Denver, Metropolitan State College and the Community College of Denver serve a combined student FTE of about 20,000 with 1,050 FTE faculty and are engaged in programs ranging from vocational to graduate and professional education. The 25 professional staff and approximately 95 FTE support staff of the Auraria Library are developing a number of innovative programs stressing a service-oriented approach. The Library participates in a cooperative, integrated online catalog system with the Colorado Alliance of Research Libraries. Salary: \$23,000-\$28,000, negotiable depending on education and experience; 12 month contract. Tuition benefits, sick leave, 22 vacation days, TIAA/CREF. For first consideration please apply by September 15, 1986. Recruitment will remain open until position is filled. Send letter of application, vita, and names, telephone numbers, and addresses of three references to: Mary Lou Goodyear, Assistant Director for Instruction and Research Services, Auraria Library, Lawrence at 11 th Street, Denver, CO 80204. AA/EEO Employer.

CONTINUATIONS LIBRARIAN, ACQUISITIONS. The Center for Research Libraries, a major interlibrary cooperative serving its member research libraries with a collection designed to complement and supplement their own, seeks a Continuations Librarian who will ensure accurate and efficient acquisition of materials for the Center's collection. Qualified candidates will have a master's degree in library science, prior supervisory experience, 2 years' professional acquisitions experience, familiarity with contemporary cataloging rules and the ability to work with foreign language materials. Prior experience with automated acquisitions systems highly desirable. Salary range: $\$ 19,600-\$ 29,400$. Persons wishing to apply for this position should

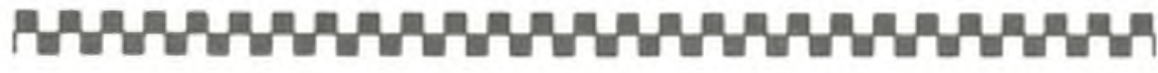 DIRECTOR OF LIBRARY SERVICES The College of Wooster (Search reopened)}

Director serves as chief administrative officer of library and is responsible for all phases of library operation: budgeting, acquisitions, cataloging, reader services, bibliographic instruction, staff development and supervision. Andrews Library holds a collection of 700,000 items and is a member of OCLC and NEOMAL. Minimum requirements: MLS with minimum five years' professional library experience; second master's degree desirable; demonstrated leadership and management ability and experience. Salary: $\$ 35,000$ minimum; will reflect background and experience. Position available January 1, 1987; application deadline October 15, 1986. Send resume, transcripts and references to: Vice President for Academic Affairs, The College of Wooster, Wooster, OH 44691.

The College of Wooster is an independent liberal arts college with a commitment to excellence in undergraduate education. We wish to insure that the search identifies qualified candidates who are women or members of minority groups. Applicants belonging to these groups are encouraged to identify themselves if they wish. submit a letter of application and list of three references to: Lyn Whittington, Personnel Officer, The Center for Research Libraries, 6050 S. Kenwood, Chicago, IL 60637. Application deadline is October 1, 1986.

COORDINATOR, COLLECTION DEVELOPMENT, University of Michigan. Associate Librarian in Undergraduate Library. Manage acquisitions and course reserves operations at Undergraduate Li brary. Coordinate selection activities and select books for undergraduate library in selected subject areas. Provide reference and bibliographic instruction to Undergraduate Library users. Assist in the coordination of other public service units within the Undergraduate Library Perform related professional tasks as appropriate Re quired: Accredited MLS. Previous experience in collection development and supervision, preferably in an academic library. Knowledge of principles and procedures for bibliographic organization, acquisition, and selection. Superior communication skills, and ability to work independently and cooperatively with staff at all levels. Desired: Previous experience in the use of automated systems in collection management, previous teaching and/or reference experience in an academic library. Previous experience in preparing instructiona materials and using microcomputers in an instructional setting. Familiarity with software collection development. Minimum salary of $\$ 20,500$. Applications received by September 30, 1986, will be given first consideration. Apply to: Library Personnel Office, 404 Hatcher Graduate Library, University of Michigan, Ann Arbor, MI 48109-1205. The University of Michigan is a non-discriminatory, affirmative action employer

COORDINATOR, INFORMATION SERVICES. Deadline extended. Responsible for coordinating and supervising professional and support staff in reference, circulation, interlibrary loan, government documents, database searching, bibliographic instruction, and special collections. Expected to teach one library course per year. Requires an ALA-accredited MLS, with 3-5 years academic library experience in public service, and appropriate supervisory experience. Ability to communicate effectively with students, faculty, and staff. A second master's degree and familiarity with automated library systems are desirable. Salary minimum $\$ 25,000$ for a twelve month tenure track position. Faculty rank and status. Send letters of application, resume, transcripts, and three current letters of reference relevant to this position by October 1, 1986, to: Anne Harman, Georgia College Library, Milledgeville, GA 31061. This position will be filled only if suitable applicants are found. Georgia College is an equal opportunity, affirmative action employer.

COORDINATOR OF ACCESS SERVICES (New position). Assists in developing access and document delivery programs utilizing new technologies. Manages Interlibrary Loan Service and Current Journals, Microforms, and Media Room. Coordinates supervision of 7.5 staff plus student assistants. Participates in reference service, collection development, database searching, and library instruction programs. Requires ALA-accredited Master's degree and minimum two years professional public services experience. Strong management ability and communication skills required. Experience with ILL highly desirable. Salary in low to mid-20's. Excellent benefits package choice of retirement programs; no state or local income tax. The University of Houston-University Park Libraries holdings exceed 1.4 million volumes, with a current materials budget of $\$ 2.6$ million. Tota staff exceeds 250. The Library is a member of ARL. Applications will be accepted until September 30,1986, or until position is filled. Send letter of application, names of 3 references, and resume to: Dana Rooks, Assistant Director for Administration, University of Houston University Park Libraries, 4800 Calhoun, Houston TX 77004. Equal opportunity employer.

COORDINATOR OF LIBRARY MEDIA SERVICES/MEMBER OF THE FACULTY, The Evergreen State College. Experienced, ener getic and innovative media professional sought to assume leadership of the Media Services area of The Evergreen State College Library, including the Media Production Center, Photo Services, and Electronic Media (Video, Audio and Projection Services). As the manager of Media Services the incumbent will actively encourage and develop methods, policies and procedures that interface services with the needs of the College, and will coordinate the preparation and control of an annual operating budget of approximately $\$ 400,000$. The position is a Member of the Faculty and rotates periodically into the teaching faculty. Qualifications: Significant experi ence in non-print media and communications required. Master's De gree required with specialization in media and communications or 
Library Sciences (ALA-accredited) or related fields preferred. Demonstrated success in administration, preferably in media services or libraries. Demonstrated ability to communicate with students, faculty and staff. Proven ability to supervise and motivate employees. Background and experience in designing, developing and teaching media communications skills at the college level preferred. Ability to teach analysis and criticism of media. Proven ability to create media productions. Knowledge of computer applications in media preferred. Compensation: Nine-month academic appointment with halftime summer work usually available. Faculty salary scale, based on education and years of experience to a maximum beginning level o $\$ 35,000$. Major medical, TIAA/CREF. For position description and application, contact: Dean of Library Services, The Evergreen State College, Olympia, WA 98505; (206) 866-6000, ext. 6246. The search committee will begin screening files on October 1, 1986. The Evergreen State College is an equal opportunity employer and operates under an affirmative action policy.

COORDINATOR OF SERIALS CATALOGING (Re-opened) The University of Arizona Library is seeking a librarian to fill the position of Coordinator of Serials Cataloging in the Serials Department. Major responsibilities include reorganizing two serial cataloging units into one integrated section, performing complex serial cataloging and problem resolution, and training beginning professional serials catalogers. The position is responsible for coordinating cataloging activities for two professional librarians and two career staff; and for monitoring liaison work and problem resolution with the monographic Catalog Department. Serials catalogers perform original subject and descriptive cataloging for serials in a number of language and subject areas using AACR2, LC subject headings and LC classification as well as some local classification schemes. The position reports to the Head Serials Librarian. Requirements include an ALA. accredited MLS and working knowledge of at least one foreign language. Applicants must have four or more years of serials cataloging experience, supervisory experience, demonstrated leadership and planning skills, the ability to communicate effectively and to work in a rapidly changing environment. Applicants should have experience with AACR2, LC classification, LC subjects, and a bibliographic utility, preferably OCLC. Salary: $\$ 23,000$ or higher depending on qualifications. Librarians at the University of Arizona have academic professional status, are voting members of the faculty, have 12-month appointments with 22 days of vacation, 12 days of sick leave and 10 holidays. Applications received by October 31, 1986 will receive first consideration. Send letter of application, resume, and the names o three references to: $W$. David Laird, University Librarian, University of Arizona Library, Tuscon, AZ 85721 . Position available immediately. The University of Arizona is an Equal Employment Opportunity, Affirmative Action employer

DEAN OF LIBRARY SERVICES. Reports to VP for Academic Affairs and is member of Council of Deans. Responsible for management of all aspects of General Library's programs, resources, services and represents the General Library at state, regional, and national levels. Must have demonstrated expertise at upper levels of academic library administration, as well as broad knowledge of computerized information technologies, demonstrated organizational leadership and interpersonal skills. Must exhibit a commitment to academic excellence and have sufficient scholarly, professional achievements to merit appointment at senior faculty rank. Will comply with policies of the Faculty Handbook irıcluding research, publication and service to profession and community. Minimum of MLS from an ALA-accredited program required and additional graduate degree desirable. The General Library consists of main library, business, curriculum and fine arts branch libraries; a new science/engi neering library is currently under construction. Staff of 40 librarians with faculty rank, over 100 staft, and 200 student assistants. Salary: negotiable; $\$ 60,000$ minimum. Nomination and Application dead line September 30,1986 (vita, 3 professional references with phone numbers). Send application to: John R. Rinaldi, Chair, Dean of University of New Mexico Library Services Search Committee, Albu querque, NM 87131. AA/EOE.

DIRECTOR OF LIBRARY SERVICES. Sioux Falls College, a Chris tian 4-year, liberal arts institution seeks Director of Library Services to be responsible for the services of a college library including supervising professional, clerical and student staff. Qualifications: ALA/MLS professional academic library experience. Salary $\$ 18,000$ to $\$ 24,000$. To apply send letter of application, current resume and references by September 15, 1986, to: Vice President of Academic Atfairs, Sioux Falls College, Sioux Falls, SD 57105

EDUCATION LIBRARIAN, University of Minnesota Libraries-Twin Cities. The Humanities/Social Sciences Libraries Department seeks qualified applicants for the position of Education Librarian. The Education Librarian reports to the Head of Humanities/Social Sciences Reference Services. Responsibilities include the following: 1) selects

\section{ASSISTANT DEAN FOR AUTOMATION \& TECHNICAL SERVICES University of Nebraska-Lincoln (tenure-leading)}

Starting January 1, 1987. 1) Plans for and coordinates the utilization of new technologies to enhance library operations and services with the long range goal of an integrated library system linked with national and regional networks. Prepares documentation for recommendations including feasibility studies, statistical analyses, and systems specifications. 2) Administers all phases of technical services operations, including acquisitions, serials, binding, and cataloging. Provides strong leadership and reviews and analyzes existing technical services operations and makes recommendations for systems improvements. Plans and organizes the activities of technical services with other library units. The Assistant Dean will be expected to integrate organizational change with technological development. 3) Oversees the implementation of systems decisions including both the acquisition and integration of new systems and the enhancement of existing systems.

Required: MLS from an ALA-accredited library school; experience with library automated systems and/ or systems planning; and evidence of continued professional growth and administrative responsibility in technical services with a demonstrated record of creative leadership. $\$ 42,000$ minimum for a 12-month contract. Salary may be higher depending upon the qualifications of the successful applicant.

Apply with full resume plus names and current addresses/telephone numbers of three references by October 15, 1986, to: Kent Hendrickson, Dean of Libraries, 106 Love Library, University of Nebraska-Lincoln, Lincoln, Nebraska 68588-0410. 
materials to support the instruction and research programs in assigned subjects; 2) analyzes, develops, and manages collections according to the University needs; 3) prepares budget requests and manages an acquisitions budget; 4) serves as library liaison with the College of Education (consults with other faculty and bibliographers as necessary and appropriate); 5) provides both introductory and specialized bibliographic instruction; 6) offers general reference service during scheduled desk hours and specialized reference consultation by appointment; 7) searches online databases. Required qualifications are an MLS or other master's degree from a program in library and information sciences; an undergraduate or graduate de gree in education. Desired qualifications include experience in collection development at the professional level; experience in reference service at the professional level; experience or training in online database searching; interest in participating in bibliographic instruction programs. The appointment is probationary at the Assistant Librarian rank. The incumbent will be expected to meet the Libraries criteria for continuous appointment within six years. Minimum $\$ 22,000$. This position is in the Professional/Academic series. To apply, send a letter of application, addressing in detail the requirements of this position, and a resume including references to publications, a statement of research interests, and names and addresses of three references, to: Barbara Doyle, Personnel Officer, University Libraries, 499 Wilson Library, 309 19th Avenue South, Minneapolis, MN, 55455-0414. Identify with No. UL 146. Applications must be postmarked no later than October 15, 1986. The University of Minnesota is an equal opportunity employer and specifically invites and encourages applications from women and minorities.

FINANCE/PUBLIC POLICY REFERENCE LIBRARIAN. Responsibilities: The Finance/Public Policy Reference Librarian will use pro- fessional skills in support of the finance, accounting, economics, and public policy areas in the business and public affairs programs on campus. Collection development, specialized reference work, computer assisted research, and specialized library instruction are part of faculty liaison responsibilities. Additionally, the successful candidate will be involved in general reference work and library instruction. Some weekend and evening work required. Other faculty responsıbilities include service and scholarly work. Qualifications: an ALA-accredited master's degree and an academic degree or experience in one of the following areas: accounting, finance, economics, public policy are required. Preferred are reference, online searching, and teaching experience. Background: the Auraria Library occupies a unique position as the central point of information services in support of the programs of 3 diverse academic institutions on one campus as well as being the only academic library in the Denver downtown area. The University of Colorado-Denver, Metropolitan State College, and the Community College of Denver serve a combined student FTE of approximately 20,000 with 1,050 FTE faculty. The 25 professional staff and approximately 95 FTE support staff of the Auraria Library are developing a number of innovative programs stressing a service-oriented approach. The library participates in a cooperative, integrated online catalog system with the Colorado Alliance of Research Libraries. This librarian works with the management/business reference librarian to support the public administration program at the University of Colorado-Denver and the business programs at all 3 schools on campus. The public administration program offers master's and doctorate level degrees, while the business programs offer courses ranging from introductory level through master's level. Salary: \$19,000-\$29,000 for a 12-month contract negotiated depending on education and experience. Tuition benefits, sick leave, 22 vacation days, TIAA/CREF. For first consideration

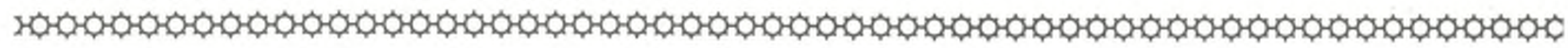

\section{PRESERVATION OFFICER University of Michigan}

The Preservation Officer will hold a joint appointment with the University Library and the School of Information and Library Studies with the greater amount of time with the Library. The incumbent will be responsible for managing a major and comprehensive preservation program, for initiating a statewide cooperative program involving educational activities and preservation services, and for participating in the expansion of preservation education in the School of Information and Library Studies curriculum. Incumbent is responsible for the design, implementation and administration of a comprehensive preservation program for the University Library. Department functions include: identification and replacement of brittle materials, bindery preparations, preservation microfilming, conservation and book repair, staff and user preservation education, stacks cleaning, disaster planning and recovery, and provision of preservation supplies and equipment for all units in the Library.

Currently, the staff of the Preservation Department consists of two librarians, four professional staff, three bookbinders, three conservation staff, two camera operators, three clericals, and 6.3 student assistants. The non-personnel budget exceeds $\$ 400,000$. The incumbent will also have the title of Lecturer in the School of Information and Library Studies and will coordinate the preservation education program of the School including teaching a course in the masters curriculum, supervision of research projects, internships, and field experiences. The incumbent, working with the Library and the School, will be responsible for designing and implementing a progressively expanding statewide cooperative preservation program. This will involve the design and presentation of a variety of training and educational activities including workshops, bench experience, and fellowships. In addition, preservation services will also be offered including conservation and microfilming, consulting, current awareness activities and disaster assistance.

Requirements: Demonstrated ability as a manager including strong communication skills, both written and oral, ability to conceptualize and organize programs, develop and direct staff, plan and monitor budgets. Ability to market statewide preservation programs and work effectively with multiple agencies in running the program. Success in teaching and/or training activity. Sound knowledge of preservation activities and issues desired and/or strong background in collection development and management. Rank of Librarian with a salary range of $\$ 30,000$ to $\$ 40,000$, dependent on directly relevant experience. Applications will be reviewed beginning September 15, 1986.

Apply to: Library Personnel Office, 404 Hatcher Graduate Library, University of Michigan, Ann Arbor, MI 48109. 
please send letter of application and names, addresses, and phone numbers of 3 references to: Joan Fiscella, Auraria Library, Lawrence at Ilth, Denver, CO 80204, postmarked by September 30, 1986. Re cruitment will remain open until position is filled. AA, EEO employer.

\section{FOREIGN LITERATURE BIBLIOGRAPHER \& REFERENCE LI-} BRARIAN. Requirements: MLS (ALA-accredited). Substantial academic library experience in collection development and maintenance in the humanities including foreign languages and literature. Desired qualifications: Reference experience; advanced degree. Ph.D. preferred, in either comparative literature or one of the following modern literatures: Spanish, German, French or Russian; teaching experience on the academic level; experience in using online systems. Demonstrated ability to work effectively with research oriented faculty, library staff, and other members of the academic community in an intellectually challenging environment. Main responsibility is development and maintenance of the collection in for eign languages and comparative literature, and allied humanities disciplines. Participates in reference service part-time, providing general and specialized reference service. Works closely with othe members of the library staff and the humanities teaching faculty, teaches a course in the Department of Foreign Languages and Literatures during Fall and Spring semesters. Members of library faculty must meet Purdue University requirements (excellence in librarianship, publishing, research, and service) for promotion and tenure Faculty status and responsibilities; rank commensurate with education and experience. 12 month appointment with 22 days vacation Group life, major medical, and disability insurance plans are in effect as are TIAA/CREF and social security. Salary: $\$ 18,000$ and up depending on qualifications. Application deadline October 1, 1986 Send resume and list of references to: Thomas L. Haworth, Personnel Officer, Libraries, Stewart Center, Purdue University, West Lafayette, IN 47907. An Equal Opportunity, Affirmative Action Employer.

GOVERNMENT PUBLICATIONS LIBRARIAN (Entry-level Position). The University of California, Irvine, has an entry-level position at the Assistant Librarian rank at a salary of $\$ 24,012$. Upward adjustment will be made for additional advanced degree. Applications received by 1 September will receive first consideration, but applica tions will continue to be accepted until the position is filled.
Responsibilities: Under the general direction of the Head of the Government Publications Department, this position is responsible for the development and bibliographic control of the U.S. collection and for participation in the full range of departmental activities including substantial reference service for all collections on a scheduled basis with some evening and weekend hours, database searching, bibliographic instruction, and policy and procedure development. Qualifications: MLS degree, interest in U.S. Government Publications database searching, and library instruction. Applicants should have a strong commitment to effective public service and an interest in the broad range of activities requisite for expected professional development. Strong verbal and written communication skills. Ability to work effectively with library users and staff. A second master's degree in the social sciences is desirable. To apply for the position: Send application letter with: 1) a complete statement of qualifications; 2) resume of education and relevant experience; and 3) the names, addresses. and telephone numbers of three references. Letters should be addressed to: Karen Nassaur, Library Personnel Office, University Library, University of California, Irvine, P.0. Box 19557, Irvine, CA 92713. Telephone: (714) 856-5408. An affirmative action, equal opportunity employer

HEAD, ARCHITECTURE \& ENVIRONMENTAL DESIGN LIBRARY at Arizona State University, home of significant special collections on Paolo Soleri and Frank Lloyd Wright. The library is located within the School of Architecture and is staffed by one professional (the Head), 2.0 FTE support staff, and student assistants. The librarian reports to the Associate University Librarian for Public Services and is responsible for management of the branch collection development, reference and research assistance, bibliographic instruction, and liaison with the college and the main library. Required qualifications: ALA-accredited MLS or foreign equivalent public service experience in an academic, research, or special library; demonstrated managerial, communication and interpersonal skills; subject expertise in one or more of the fields of architecture, art history, interior design, landscape architecture, urban design and city planning. Preferred: administrative experience in a branch, unit or department, preferably in an academic library; a minimum of 3 years' public service experience in an academic or research library. Salary: dependent on qualifications ( $\$ 23,000$ and up). Send letter of

\section{Cleveland State University Director of University Libraries}

Cleveland State University is seeking an energetic and innovative Director of Libraries.

Minimum Qualifications: an M.L.S. Degree from an ALA-accredited program, successful administrative experience in an academic or research library, and sound knowledge of all aspects of academic library operations, including collection development and management, bibliographic control and management, automated systems and services, resource sharing, academic budgeting, fundraising, and grantsmanship.

Preferred Qualifications: an advanced degree in an academic or professional discipline, and evidence of a continuing commitment to scholarly and professional development.

The Cleveland State University Libraries are housed in a single, centrally-located facility. Its collections contain over 550,000 volumes. Cleveland State University is a state-supported, urban university of seven colleges serving approximately 18,000 undergraduate and graduate students. Located in the revitalized downtown area of Cleveland, the University is within blocks of major cultural institutions, including Playhouse Square, The Cleveland Museum of Art, The Cleveland Orchestra, The Cleveland Playhouse, and The Cleveland Public Library.

Salary and benefits are competitive ( $\$ 57,000$ salary minimum).

Nominations or applications should be sent by October 10, 1986, to: Richard H. Swain, Chair, Search Committee for Director of Libraries, Cleveland State University Libraries, 1983 East 24th Street, Cleveland, Ohio 44115. Cleveland State University is an Equal Opportunity Employer.

\section{C11 Cleveland State University}


application which addresses each of the qualifications listed above, a current resume, and the names, addresses and numbers of four recent references to: Constance Corey, Assistant University Librarian, Hayden Library, Arizona State University, Tempe, AZ 85287. Recruitment will remain open until the position is filled. To ensure consideration, applications should be received by October 31 1986, when review will begin. ASU is a committed Equal Opportunity, Affirmative Action Employer. Women and minorities are encouraged to apply.

HEAD, CENTRAL SCIENCE LIBRARY (CSL), University of Florida Environment: Scheduled for occupancy in early 1987, the CSL will house a staff of 35 FTE, approximately 440,000 volumes and 650,000 microforms, and will serve the research and instructional needs of faculties and students in the disciplines of agriculture, as tronomy, biological sciences, chemistry, computer and information sciences, geology, engineering, mathematics, physics and statis- tics. Responsibilities: Oversees the services and operations of the CSL; bears principal library responsibility for CSL communication with the science faculties, for the development of policies and goals, for coordination with the Collection Management, Public Services, and Technical Services Divisions, and the effective operation of the CSL; participates with the directors and other library managers in general library planning, budgeting, policy making, setting of priorities and fund raising; coordinates collection management and development activities of the CSL collections. Requirements: ALAaccredited MLS; academic preparation equivalent to at least a bachelor's degree in a science/technology area covered by the CSL or the demonstrated equivalent; demonstrated administrative competence in the management of library operations; substantial applicable reference and collection development experience (6-8 years); demonstrated professional accomplishment relevant to the responsibilities of the position; demonstrated capacity to work effectively and congenially with faculty, students, and staff and to communicate effectively orally and in writing. Benefits: tenure track appointment

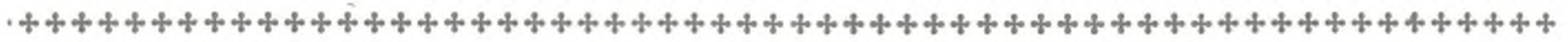

\section{COORDINATOR OF AREA PROGRAMS}

\section{University of Michigan}

The Coordinator of Area Programs is responsible for overseeing the library's four area program divisions: Near East, Slavic, South Asia, and Southeast Asia. In addition to responsibilities as Head of one of the four divisions, the Coordinator is responsible for: developing and monitoring plans and budgets for area programs; representing and coordinating collection development interests of area programs; coordinating technical processing functions; and developing programs/proposals to enhance the services and collections of area programs. Area program staff total 11 FTE with collection budgets of over $\$ 176,000$. The Coordinator reports to the Head of the Graduate Library.

Candidates for Head of the Near East Division and Head of the Slavic Division (described below) will be considered for this coordinating position. Individuals who are interested in these additional responsibilities should indicate their interest and qualifications in their application for one of the two positions below.

\section{Head, Near East Division}

The Near East Division of the University of Michigan's Graduate Library is responsible for the acquisition, cataloging, and outreach services associated with Near East Collections. The Head of the Near East Division supervises three (1.83 FTE) catalogers/collection development librarians, develops and manages collections in vernacular languages, coordinates collection activities with librarians handling non-vernacular languages, acts as a liaison with Center for Near Eastern and North African Studies. Requires: MLS, MA in area of Near Eastern Studies; reading knowledge of Arabic and working knowledge of other Near Eastern languages (modern and ancient); progressively advanced experience in cataloging, acquisitions, and/or reference work in a research library; strong oral and written communication skills. Desired: Ph.D; demonstrated experience in cooperative collection development, collection assessment; knowledge of computer systems; supervisory experience.

\section{Head, Slavic Division}

The Slavic Division of the University of Michigan's Graduate Library is responsible for the acquisition, cataloging, and outreach services associated with Slavic and Eastern European collections. The Head supervises 5.25 FTE, develops and manages vernacular collections, and acts as a liaison with the Center for Russian and Eastern European Studies. Required: MLS, MA in an area of Slavic or Eastern European Studies; reading knowledge of Russian and one other Slavic language; progressively advanced experience in cataloging, acquisitions, and/or reference work in a research library; strong oral and written communication skills. Desired: Ph.D; working knowledge of Eastern European non-Slavic languages; computer experience; demonstrated experience in cooperative collection development, collection assessment; supervisory experience.

For both the Head, Near East Division and the Head, Slavic Division positions, applications received by September 20, 1986, will receive first consideration. Salary range of $\$ 28,000-\$ 40,000$ dependent on previous relevant experience with additional compensation for the Coordinator of Area Programs responsibilities. Apply to: Library Personnel Office, 404 Hatcher Graduate Library, University of Michigan, Ann Arbor, MI 48109-1205. 
with faculty status, 22 days vacation, 13 days sick leave, TIAA/CREF or other retirement options, no state or local income tax. Salary: $\$ 35,000$ minimum for 12 months. Send letter of application with re sume and names, addresses, and phone numbers of 3 professional references by October 1, 1986, to: Lynn Badger, Library Personne Officer, 211 Library West, University of Florida, Gainesville, FL 32611. An AA/EO employer

HEAD, COLLECTION DEVELOPMENT AND SERVICES DIVISION. Position responsible for coordinating development of the library's collections and administering non-reference operations of the Art, Music, Curriculum Materials, and Film Services. Position wil supervise 12 staff; manage materials funds; recommend funds allo cations; manage approval program and workflow of order verification, preparation and vendoring; and coordinate handling of gift materials. Requirements: ALA-accredited MLS; minimum of 5 years professional experience in an academic or research library, including successful supervisory experience; excellent written and ora communication skills; experience in most collection development activities listed above; ability to work closely with faculty, library staft, and academic administrators; knowledge of foreign language of bibliographic importance. Desirable: knowledge of a second foreign language of bibliographic importance; experience in library acquisitions budgeting; and a second graduate degree. Salary $\$ 25,000-\$ 30,000+$ depending on experience and qualifications. Send resume and names of 3 current references by October 10 1986, to: Billie Reinhart, Chair, Search Committee for Head, Collec fion Development and Services Division, Cleveland State University ibraries, 1983 E. 24th St. Cleveland, OH 44115. EOE, m/f/h.

HEAD, GRADUATE SCHOOL OF INTERNATIONAL RELATIONS AND PACIFIC STUDIES LIBRARY, University of California, San Diego. Starting date: available immediately. Rank: Associate Librarian, $\$ 27,948-\$ 40,248$ or Librarian, $\$ 37,572-\$ 52.092$ (subject to potential salary adjustment as of July 1,1986 ). The focus of this newest school of the University of California, San Diego, au thorized by the UC Regents in January, 1986, is the interrelationships among the nations of the Pacific Basin and their political, economic, and cultural importance to the United States. Under the general direction of the Assistant University Librarian for Collections, the incumbent is responsible for planning, developing, implement ing, and managing the new branch library's collections, services, and operations; functions as primary liaison between the Pacific Studies Library and faculty, graduate students, and other scholars using the Library; hires, supervises, and monitors staff; develops and implements policies and procedures; develops and promotes special programs, especially innovative automated services; keeps abreast of developments in relevant subject areas, in information science, etc.; has selection responsibility in one or more subject areas and responsibility for coordinating collection development in Pacific Studies; has reference and instructional responsibilities for the $\mathrm{Pa}$ cific Studies. UCSD librarians are expected, as academic appoint- ees, to participate in librarywide planning and to be active profes sionally. Qualifications: MLS from an ALA-accredited library school. Applicants with experience in managing an academic library public services unit, developing research collections, and delivering automated information services will be preferred. Demonstrated communication skills, both written and oral; demonstrated ability to work effectively with faculty and other researchers; understanding of the research process and the needs of researchers in the social sciences. Desirable: knowledge of a foreign language relevant to the School's areas of interest and graduate level background in the Social Sciences and/or appropriate area studies. Appointment at the Librarian level requires substantial relevant experience. UCSD is an equal opportunity, affirmative action employer. Applications re ceived or postmarked by September 22, 1986, are assured of consideration. Submit a letter of application, enclosing a resume and a list of references to: Ellen Lawson, Assistant for Academic Personnel, Library, C-075-H2, University of California, San Diego, La Jolla CA 92093.

HEAD LIBRARIAN. McGill University Libraries requires a Head Librarian for the Islamic Studies Library. Reporting to the Area Librar ian of the Humanities and Social Sciences, the Head Librarian provides leadership and direction to the Islamic Studies Library, and is responsible for reader services and collection development, working closely with the HuSSAL Reader Services Librarian and Collections Librarian, as well as the Director and faculty of the Institute of Islamic Studies. The staff of the Islamic Studies Library consists of three library assistants and some casual assistance. The Library is unique in Canada and houses about 100,000 volumes to suppor McGill University's strong program in Middle Eastern Studies. Qualifications: MLS and an advanced degree in Islamic and Middle Eastern Studies with excellent knowledge of Arabic, a second Islamic language and familiarity with Middle East literature and culture. Severa years of professional library experience with evidence of good management skills. Must be able to represent the McGill Libraries in development endeavors and on a national level in Islamic and Middle East librarianship. Salary and rank will be commensurate with experience and qualifications, e.g. Associate Librarian rank begins a $\$ 28,802$. This is a tenure track position and it is hoped to make an appointment by June 1, 1987. Preference will be given to Canadian citizens and permanent residents of Canada. Please submit a recent Curriculum Vitae and names of three references to: Calvin Evans, Area Librarian, Humanities and Social Sciences Area Library, McGil University, McLennan Library, 3459 McTavish Street, Montreal Quebec, Canada, H3A $1 Y$

HEAD OF ACQUISITIONS (Search reopened). Requirements: Minimum of 4 years recent experience directly related to an academic library acquisitions department and/or the book trade industry, in cluding supervisory responsibilities. Desired qualifications: MLS (ALA-accredited). Ability to plan, supervise and coordinate the acquisitions of monographs, serials, and non-print materials. Knowl-

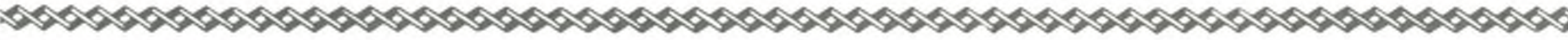 HEAD, UNDERGRADUATE LIBRARY University of Michigan}

Plans, develops, and manages the programs and services of the Undergraduate Library which includes the Microcomputer Center and the University Reserve Service. Supervises a staff of 5 librarians and 17 support staff. Manages a student hourly budget of $\$ 100,000$. Responsible for reference services, library instruction, online searching, collection management, and staff development and training. Participates as a member of the Public Services Council and the Management Advisory Council. Reports to the Associate Director for Public Services.

Required: Managerial experience in an academic library with demonstrated success in the areas of budgeting, planning, and staff supervision. Collection development and management experience. Knowledge and experience with library automation and microcomputers. A good grasp of issues and trends facing academic libraries. Demonstrated success in working with faculty, students, and computing center staff. Excellent interpersonal and communication skills. ALA-accredited MLS. Minimum salary of $\$ 35,000$.

Applications received by October 15, 1986, will be given first consideration. Apply to: Library Personnel Office, 404 Hatcher Graduate Library, University of Michigan, Ann Arbor, MI 48109-1205. 
edge of both manual and automated materials acquisition and serial control systems. Knowledge of domestic and foreign publishing trade and vendor sources/plans. Experience with gifts and exchange programs and government documents depository programs. Experience with library materials budgets. Excellent oral/written communications and interpersonal skills. Manages a staff of 1 administrative assistant and 17 support staff members in the Acquisitions Department. Responsible for the ordering, receiving, and claiming of library materials. Work with the Library's Business Office to coordinate the fiscal reporting of library materials funds. Coordinate the gifts and exchange program, binding, and distribution of library materials and supplies in a decentralized library system. Evaluate vendor performance and assist in approval plans management. Participate in the development of automated acquisitions programs. Salary: $\$ 23,000$ and up depending on qualifications. Status and Benefits: Exempt Supervisory position. Annual vacation of 15 working days during the first year of employment and 22 days thereafter. Group life, major medical, and disability insurance plans are in effect as are TIAA/CREF and social security coverage. Application deadline: October 1, 1986. Send resume and list of references to Thomas L. Haworth, Personnel Officer, Libraries, Stewart Center, Purdue University, West Lafayette, IN 47907. An Equal Opportunity, Affirmative Action Employer

HEAD OF CIRCULATION/REFERENCE LIBRARIAN. Colgate University, a highly selective, independent college located in rura upstate New York, is seeking candidates for the position of Head of Circulation/Reference Librarian. Is responsible for management of circulation department and its subunits, reserves and music room. Supervises 5.5 FTE's and 35 student assistants. Full participant in reference department programs including reference desk, documents, interlibrary loan, bibliographic instruction, and database searching. Some evening and weekend duties. Required: ALA accredited MLS, 3 years' circulation and/or reference experience, excellent interpersonal and communication skills. Preferred: experience with an automated circulation system. Salary \$23,000-\$25,000. Application deadline: October 15, 1986 Send letter of application, resume, and names of 3 references to: University Librarian, Case Library, Colgate University, Hamilton, NY 13346. Women and minorities are encouraged to apply. Colgate is an $A$ A, EOE.
HEAD OF MONOGRAPHIC ACQUISITIONS. The University of California, Irvine is recruiting for a Head of Monographic Acquisitions. Appointment range will be from Assistant to Associate Librarian. Rank and salary range is from $\$ 29,340-\$ 34,452$. Appointment at the Associate level requires substantial experience in acquisitions as well as in library automation in an academic or research library. Applications received by 15 September will receive first consideration, but applications will continue to be accepted until the position is filled. Responsibilities: Under the general direction and review of the Assistant University Librarian for Technical Services, this position is responsible for the overall management and supervision of the Monographic Acquisitions Department. This responsibility includes all management functions, such as planning, implementing, coordinating, and evaluating of operations; establishing priorities; evaluating staff performance. This person is also expected to work with appropriate units in coordinating the fiscal reporting of library materia funds and participate in the development of automated acquisitions programs. Qualifications: Required: MLS from an accredited library school; experience directly related to acquisitions functions in an academic or research library; demonstrated supervisory and administrative skills; evidence of ability to work effectively with diverse library staff and outside vendors; effective written and verbal communication skills; knowledge of domestic and foreign publishing trade and vendor sources/plans. Highly desirable: substantive knowledge of automated acquisitions systems; ability to work with a variety of mod ern European languages. To apply for the position: Send application letter with: 1) a complete statement of qualifications; 2) resume of education and relevant experience; and 3) the names, addresses, and telephone numbers of three references. Letters should be addressed to: Karen Nassaur, Library Personnel Office, University Library, University of California, Irvine, P.0. Box 19557, Irvine, CA 92713. Telephone: (714) 856-5408. An affirmative action, equal opportunity employer

HEAD, REFERENCE DEPARTMENT, Georgia State University The Reference Department offers central reference services to the entire University. The Head of the Reference Department is responsible for the administration of all reference functions. Specific duties include: directing and coordinating the delivery of reference services, online search services, bibliographic instruction, interlibrary loan service, and the government documents and maps collections;

\title{
HEAD, SCIENCE LIBRARIES DEPARTMENT LIBRARIAN
} University of California, Berkeley

Administers and defines standards for the provision of science and engineering information services at the University of California, Berkeley, which supports some of the most distinguished research and teaching programs in the nation. The department comprises 14 science libraries with a full-time staff of 48 , and combined collections of over 825,000 volumes.

Responsible for planning new library services in accordance with the changing and increasingly auto-

mated nature of science information storage, transmission, and use.

Provides overall direction for science departments, including services, staffing, and collection management programs. Coordinates department's active participation in the development of the library's automated systems for public access and technical processing.

Requires an MLS degree and extensive management experience in a scientific, biomedical, or engineering academic or research library. Experience with progressive information services within a scientific research environment is required. Experience working in a collective bargaining environment would be useful.

Full job description mailed on request. Appointment will be made in the $\$ 39,456-\$ 45,084$ per annum salary range, depending on qualifications. Starting date January 15, 1987, or as soon thereafter as possible. To apply, send a resume, including names and addresses of 3 professional references, by October 15, 1986, to:

\author{
William E. Wenz \\ Director for Library Personnel \\ Room 447, General Library \\ University of California \\ Berkeley, CA 94720
}


selecting, training, and evaluating personnel; budgeting for equip ment, supplies, and personnel; and planning for future space, staffing and other needs of the Department. The Department Head participates in library-wide planning with other department heads and appropriate committees. The library is organized into six departments; the department heads report to the Associate University Librarian. Positions in the department include thirteen librarians, seven support staff, five part-time reference librarians, and student assistants. The library collection includes 900,000 volumes and 5,000 periodical subscriptions. A library addition is scheduled for completion in 1987 and the library is in the process of reorganization. An online catalog is in its first year of operation and an integrated online circulation system will be installed this year. Required: a graduate degree from an ALA-accredited library school; a second master's or Ph.D. in a subject field preferred; evidence of substantial professional development, scholarly research, and publications; five years relevant experience in academic libraries; successful performance in progressively responsible professional positions; demonstrated management and communication skills; willingness and ability to encourage the professional development of others; a clear understanding of the role of the Reference Department and the needs of students, faculty, and staff; working knowledge of new technology in delivery of information services; analytical abilities; resourcefulness and enthusiasm. Tenure track position with faculty rank and status. Salary: minimum $\$ 31,000$ for twelve months. Available January 1987. Applications received by October 15, 1986, will receive first consideration. Submit letter of application, resume and names, addresses and phone numbers of three references to: Dianne $M$. Smith, Assistant to the Librarian, William Russell Pullen Library Georgia State University, 100 Decatur St., S.E., Atlanta, GA 30303 3081. An equal opportunity and affirmative action employer.

HEAD, REFERENCE SERVICES DEPARTMENT. Colgate University, a highly selective, independent college located in rural upstate New York, is seeking candidates for the position of Head, Reference Services Department. Is responsible for the effective management of an active, high-profile department. Operations include reference desk, documents, interlibrary loan, bibliographic instruction, and database searching, each of which is coordinated by a reference librarian. Staff includes 6 professionals, 3 support staff, and studen assistants. Required: ALA-accredited MLS, 5 years' successful experience in academic libraries, including substantial reference and some supervisory experience, experience in database searching and bibliographic instruction. Salary $\$ 25,000-\$ 30,000$. Application deadline: October 15, 1986. Send letter of application, resume, and names of 3 references to: University Librarian, Case Library, Colgate University, Hamilton, NY 13346. Women and minorities are encouraged to apply. Colgate is an AA, EOE

HEAD, SERIALS RECORDS. Assistant Professor (tenure-leading), Serials Department, starting January 1. The Section Head's major responsibilities are to provide overall supervision of the Serial Records Section, and to serve as chief revisor for the receiving records in a library with over 19,000 standing orders and a large manual file Specific duties include: overall supervision of 11 support staff; monitoring work flow and work load for staff; and maintaining the quality and quantity of the Section's output. Required: MLS from an ALAaccredited library school, a minimum of 2 years serials experience in an academic library, preferably in serials cataloging using AACR2, ability to relate well to staff and peers, good written and oral communication skills and evidence of good organizational abilities. Preferred: familiarity with the latest developments in serials automation. $\$ 19,000$ minimum for a twelve-month contract. Salary may be higher depending upon the qualifications of the successful applicant. Apply with full resume plus names and current addresses/telephone num bers of three references by October 15, 1986, to: Kent Hendrickson, Dean of Libraries, 106 Love Library, University of Nebraska-Lincoln, Lincoln, Nebraska 68588-0410. Affirmative Action, Equal Opportunity Employer

HEAD, SOCIAL SCIENCES DIVISION, with faculty rank. Position reopened. Responsible for the Social Sciences Public Service Division of the Library and its staff. Serve as business administration and economics resource person, and direct collection development for

\section{TWO DEPARTMENT HEAD POSITIONS}

Ohio University Libraries

Head, Archives and Special Collections, to manage the University Archives, records center, rare book and manuscript collections, local government records and other special materials. Collecting focus on Ohio history, English literature, history of chemistry, and history of journalism. Serves as Executive Secretary of the Friends of the Library. May teach course in archives administration for added compensation by History Department. Requirements: (a) ALA-accredited MLS degree, (b) 3 years professional library experience, with at least 1 in archives/rare books, (c) familiarity with automated library systems, (d) leadership, supervisory and communications skills. Preferred qualifications: (a) additional graduate degree in history or literature, (b) experience in fundraising, grantsmanship, and Friends groups, (c) familiarity with microcomputer applications in the archival setting.

Music/Dance Librarian, to head an on-campus branch library housing 50,000 books, periodicals, scores, sound recordings, and extensive listening facilities. Requirements: (a) ALA-accredited MLS degree, (b) 3 years professional library experience, (c) broad knowledge in all areas of music, with some expertise in dance, (d) strong leadership, supervisory and communications skills, (e) familiarity with automated library systems. Preferred qualifications: (a) additional graduate degree in music, (b) reading knowledge of one major European language, (c) familiarity with microcomputer applications in libraries.

Both positions report to the Associate Director of Libraries for Special \& Subject Collections. Twelvemonth annual administrative contract, with excellent health and state retirement benefits, 22 annual vacation days, and full tuition remission for dependants. Salary: $\$ 23,000$ to $\$ 30,000$ for both positions, depending on qualifications. Both jobs to begin January 1, 1987.

Founded in 1804, Ohio University is a state-supported institution with an enrollment of 20,000 and comprehensive educational programs. Located in the college town of Athens, it offers a beautiful residential campus situated amid the rolling hills of Appalachian Ohio.

Send letter specifying position, with resume and 3 references by October 17, 1986, to: Gary A. Hunt, Associate Director, Ohio University Libraries, Athens, OH 45701. 
materials in the social sciences. Supervise the work of three professionals, three nonprofessionals, and one student assistant. Serve students and faculty at the reference desk; hold a position on library director's administrative council and serve on council committees concerned with overall library operation. Master's degree from an ALA-accredited library schcol; a bachelor's or second master's in the social sciences, preferably in economics and/or business administration; at least five years experience in an academic library public services position, preferably in the social sciences area. Initial appointment with faculty rank of instructor with advancement to Assistant Professor at end of first year if merited. Good fringe benefits. Salary: $\$ 27,600$ minimum. For full consideration applications should be received by October 15,1986 . Submit letter of application with resume including names of three references to: Roscoe Rouse, University Librarian, Oklahoma State University, Stillwater, OK 74078. AA/EO Employer.

HISTORICAL COLLECTIONS CATALOGER, Health Sciences Library. The College of Physicians of Philadelphia is seeking applicants for this position, available immediately. Responsibilities include original and copy cataloging of pre-1901 monographs in the Rare Book and Manuscripts Department of the Library. Qualifications: ALA-accredited MLS, 1-2 years cataloging experience on OCLC, preferably using NLM classification and Medical Subject Headings $(\mathrm{MeSH})$, knowledge of the principles and procedures of descriptive bibliography and rare book terminology, familiarity with rare book bibliographies and other reference tools, and reading knowledge of Latin, German, and French. Excellent fringe benefits. Minimum salary: $\$ 17,000$. Submit resume, listing three references, by October 15, 1986, to: Curator, Historical Collections, College of Physicians of Philadelphia, 19 South 22nd Street, Philadelphia, PA 19103. An equal opportunity, affirmative action employer.

HUMANITIES LIBRARIAN. The University of California, Irvine invites applications for the position of Humanities Librarian in the Main Library. This is an entry-level appointment at the Assistant Librarian rank at a salary of $\$ 24,012$. Upward adjustments may be made for appropriate advanced degrees. Applications received by October 15, 1986, will receive first consideration, but applications will be accepted until the position is filled. Responsibilities: The incumbent

\section{DIRECTOR OF LIBRARIES}

\section{Loyola University Law Library}

Loyola University invites nominations and resumes for the position of Director of Libraries. Loyola has 4 campuses and a diverse educational program in 10 colleges and schools, including both day and evening divisions; student enrollment of 16,000 and faculty of 1,398. Each campus has a library. The total collection is 925,000 volumes. Responsibilities include budget preparation, administration, collection development and implementation of automation. Reports to the Senior Vice President and Dean of Faculties.

In addition to appropriate educational background, candidates should have administrative experience in academic libraries, evidence of continuing professional development, and good interpersonal skills. Detailed job description and qualification requirements available upon request. Salary $\$ 40,000-\$ 50,000$. Contact: Francis Doyle, Loyola University Law School, 1 E. Pearson St., Chicago, IL 60611 by October 3, 1986.

Loyola University is an Equal Opportunity, Affirmative Action em ployer and invites and encourages applications from women and minorities. serves as a reference librarian reporting to the Head of Reference and as a bibliographer reporting to the Head of Collection Development. The reporting line is through the Reference Department. Reference librarians in the Main Library share responsibility for general and specialized reference service (including evening and weekend assignments). These responsibilities include reference desk assistance to library users in conceptual, intellectual, and bibliographic access to information; database searching; and bibliographic instruction. The incumbent functions as a liaison with the School of Humanities, and specifically with the Department of English and Comparative Literature, the Department of Classics, the Department of Philosophy, and the Program in Linguistics. As a bibliographer, the incumbent shares with the Head of Collection Development and other bibliographers the responsibility for development and management of all library collections, with special responsibility for developing and maintaining materials to support the research and instructional needs of faculty and students in the School of Humanities, and specifically in the Department of English and Comparative Literature, the Department of Classics, and the Program in Linguistics. Qualifications: Required: ALA-accredited MLS degree; degree in English and Comparative Literature or commensurate experience. Demonstrated commitment to public service; excellent oral and written communication skills. Ability to work effectively, independently and cooperatively with all elements of the academic community. Desirable: Additional graduate degree in English and Comparative Literature or Classics. Experience in collection development, bibliographic instruction, and database searching. To apply: Send application letter with 1) a complete statement of qualifications; 2) resume of education and relevant experience; and 3) the names, addresses, and telephone numbers of three references. Letters should be addressed to: Karen Nassaur, Library Personnel Office, University of California, Irvine, P.O. Box 19557, Irvine, CA 92713. Telephone: (714) 856-5408. An affirmative action, equal opportunity employer.

IBERO-AMERICAN COORDINATOR. Reports to the Asst. Dean for Collection Development, responsible for managing acquisitions of Ibero-American materials, including selection in several subject areas, monitoring ibero materials budget, coordinating work of 2-3 other selectors, working closely with Latin American Institute and staff on long-range planning for collections. Participates in planning for overall collection development with Assistant Dean and 4 other coordinators. Required: MLS from ALA-accredited program; a minimum of three years' experience working with Latin American selection and acquisitions in a research library; fluency in written and spoken Spanish and working knowledge of Portuguese. Graduate degree in Latin American studies strongly preferred. Additional qualifications include strong communication skills, experience with grant writing, knowledge of Latin American and Iberian book trades; ability to develop and implement long range plans. Incumbent must comply with policies of Faculty Handbook including research, publication and service. Salary: $\$ 24,000$ minimum depending on qualifications. To ensure fullest consideration please submit resume including names and addresses of three references by September 26, 1986 to: Claudia Dean. Personnel Office, General Library, University of New Mexico, Albuquerque, NM 87131. The search committee will continue to review applications until the position is filled. AA/EOE

LIBRARIAN OF AFRICANA, Northwestern University Library. Formulates and coordinates public service programs of the Herskovits Library; supervises support staff; and selects material for designated portions of the Africana collection. Qualifications: MLS from accredited library school. At least three years of professional public services experience; supervisory experience desirable. Strong Africana background highly desirable; strong working knowledge of German or Portuguese (preferred) or of French; knowledge of MARC bibliographic formats and of online library systems desirable. Demonstrated ability to communicate effectively at all levels. Salary: $\$ 24,000-\$ 28,000$, dependent upon qualifications and experience. Send letter of application and resume, including names of three references to: Lance Query, Director of Library Research, Analysis, and Personnel, Northwestern University Library, Evanston, IL 60201. Applications received by October 15, 1986, will be considered. EEO/AA.

MANAGEMENT REFERENCE LIBRARIAN. Specializes in full range of information and reference services for students and faculty of Northwestern University's Kellogg Graduate School of Management and participates in general social sciences and humanities reference programs. Assists in planning and development of the Man- 
agement Services departmental programs, and has special responsibility for undertaking new initiatives within the Library relating to computer-based library technologies in support of the Graduate School of Management. MLS from accredited library school required. Academic background in economics or other business-related discipline and advanced degree preferred. Business reference or general reference experience, and training in computerized literature searching required. Starting salary range: $\$ 21,000-\$ 24,000$ depending upon qualifications. Send letter of ap plication and resume, including names of three references, by September 30, 1986, to: Lance Query, Personnel Librarian, Northwestern University Library, Evanston, IL 60201. An Equal Opportunity, Affirmative Action Employer.

MUSIC SPECIALIST LIBRARIAN. Anticipated opening. Partici pates fully in all aspects of branch library operation including general reference services (some evening and weekend duties on a rotating schedule), bibliographic instruction, online database searching, collection maintenance, and technical services processes for music materials. Supervises one full time staff position and student assistants. This is a 12 month faculty position and reports to the Head of the Music Library. The Music Library, located in the ECU School of Music, is a branch collection of Joyner Library and is staffed by 2 librarians and 2.5 support staff. Joyner Library serves a campus community of over 14,000 students and 750 faculty. East Carolina University is part of the 16 campus University of North Carolina System. Qualifications required: ALA-accredited MLS degree; advanced degree in music (or substantial progress toward same); working knowledge of modern European languages; experience with AACR2, LC classification, and OCLC cataloging of music materials; effective oral and written communication skills. Familiarity with online database searching and automated library systems and experience in a university or special library are preferred. Minimum salary $\$ 22,000$. Send letter of application, resume, official transcripts, and names of three current references to: Ruth M. Katz, Director of Academic Library Services, Joyner Library, East Carolina University, Greenville NC 27858-4353. Applications must be postmarked on or before October 10, 1986. East Carolina University is an AA/EEO employer.

PHYSICS/ASTRONOMY LIBRARIAN. University of Illinois Library at Urbana-Champaign. Permanent position available immediately
Librarian is responsible for all aspects of administration and operation of Physics/Astronomy Library. With materials budget of approximately $\$ 120,000$, the librarian, in cooperation with the faculty, is responsible for collection development in physics, astrophysics, and astronomy. Librarian assures that reference, original cataloging, and other services are provided to meet library needs of faculty, students, and allied personnel in areas served. Librarian maintains strong working relationship with faculty, administration, and other related units and engages in instructional and promotional activities for the library. Active participation in research and professional service complements library responsibilities. Required qualifications: Master's degree in Library Science from ALA school, or equivalent; minimum three years professional academic, research, or special library service with increasing responsibility and including experience in public services, supervision, and administration; knowledge of, or experience in, literature of physical sciences and/or engineering and the needs of researchers; ability to work with diverse research oriented clientele; evidence of ability to meet university standards of research, publication, and service. Preferred qualifications: Experience in collection development, cataloging, reference, or bibliographic instruction; familiarity with automated information systems and services. Desired qualifications: Undergraduate degree in physical sciences. $\$ 25,000$ upward Assistant Professor level; $\$ 28,000$ upward Associate Professor level; level of appointment depends on qualifications and scholarly credentials. Send letter of application with complete resume and riames and addresses and telephone numbers of five references to: Allen G. Dries, Library Personnel Manager, University of Illinois Library at UrbanaChampaign, 127 Library, 1408 West Gregory Drive, Urbana, IL 61801. Phone (217) 333-8169. Application and nomination deadline November 3, 1986. AA/EEO Employer.

PSYCHOLOGY LIBRARIAN, University of Minnesota LibrariesTwin Cities. The Humanities/Social Sciences Libraries Department seeks qualified applicants for the position of Psychology Librarian The Psychology Librarian reports to the Head of Humanities/Social Sciences Reference Services. Responsibilities include the following: 1) selects materials to support the instruction and research programs in assigned subjects; 2) analyzes, develops, and manages collections according to University needs: 3) prepares budget requests and manages an acquisitions budget; 4) serves as library liaison with the Department of Psychology (consults with other faculty and bibli-

\section{CURATOR, YALE COLLECTION OF AMERICAN LITERATURE Beinecke Rare Book and Manuscript Library Yale University}

Yale University's Beinecke Library seeks a Curator to oversee the growth, organization, interpretation, and conservation of the Yale Collection of American Literature, an outstanding collection of literary texts and manuscripts. Responding to new opportunities as well as to the traditional strengths of the Collection, the Curator formulates collection development policies and selects a broad range of materials. The Curator also works with the cataloging, conservation, and preservation units of the Library to fill the needs of the collection in those areas, provides specialized reference assistance, coordinates routine reference service for the collection and interprets the collection's holdings for a broad public through exhibitions and special programs. In addition, the Curator participates in policy decisions and planning at the Beinecke and may be assigned special library-wide projects.

Qualifications: Ph.D. in American literature or an area of American studies, or an equivalent depth of knowledge. ALA-accredited MLS desirable. Evidence of bibliographical and scholarly accomplishment and knowledge of trends in scholarship. Several years of relevant professional experience. Ability to plan and execute effective programs and to manage diverse collection activities. Commitment to organizational and technological change. Excellent interpersonal and communication skills.

Salary and benefits: Salary and rank commensurate with qualifications (from a minimum of $\$ 23,500$ ). Benefits include 22 days vacation; 16 holiday, recess, and personal days; comprehensive health care; and relocation assistance.

To be assured of consideration, please submit letter of application, resume, and the names of three references by October 1, 1986, to: Linda Green, Assistant Personnel Librarian, Yale University Library, P.O. Box 1603A Yale Station, New Haven, CT 06520. 
ographers as necessary and appropriate); 5) provides both introductory and specialized bibliographic instruction; 6) offers general reference service during scheduled desk hours and specialized reference consultation by appointment; 7) searches online databases. Required qualifications are an MLS or other master's degree from a program in library and information sciences; an undergraduate or graduate degree or a secondary concentration in psychology. Desired qualifications include experience in collection development at the professional level; experience in reference service at the professional level; experience or training in online database searching; interest in participating in bibliographic instruction programs. The appointment is probationary at the Assistant Librarian rank. The incumbent will be expected to meet the Libraries' criteria for continuous appointment within six years. Minimum salary is $\$ 22,000$. This position is in the Professional/Academic series. To apply, send a letter of application that relates your experience and background to the requirements of the position. In addition, please enclose a current vitae including the names and addresses of three references. Please send these to: Barbara Doyle, Personnel Officer, University Libraries, 499 Wilson Library, 309 19th Avenue South, Minneapolis, MN, 55455-0414. Identify applications with No. UL 145. Applications must be received by October 15, 1986. The University of Minnesota is an equal opportunity employer and specifically invites and encourages applications from women and minorities.

REFERENCE LIBRARIAN/BIBLIOGRAPHER FOR FOREIGN LANGUAGES AND LITERATURES. Librarian II, University of
Rochester. New position. Research-oriented university library (RLG member) with expanding research and teaching programs in foreign languages and literatures seeks innovative reference bibliographer able to develop and maintain collection development and reference services in the language, literatures and cultures of the German speaking countries. Additional familiarity with Spanish (including Hispano-American) language and literatures highly desirable. Emphasis is on the quality of understanding of the literatures and their criticism and on the ability to maintain supportive communication with faculty and students in the fields. Flexibility and initiative are a must, as the successful candidate will serve as a member of a forward-looking team of librarians and support staff who provide bibliographic instruction, online searching and instruction, and genera reference assistance including shared work on evenings and week ends. Receives general direction from the Head, Reference Department, and consults with the Chief Collection Development Officer Qualifications: ALA-MLS; minimum of BA-level training in German with a good reading knowledge of Spanish; some previous academic library experience; ability to communicate clearly both orally and in writing with faculty, staff and students. Salary $\$ 21,000+$ de pending on qualifications and experience. Send a letter of applica tion that describes your experience in terms of the requirements of this position, together with a resume and the names of three references, to: Language Reference Search, Director's Office, University of Rochester Libraries, Rochester, NY 14627. Recruitment will remain open until position is filled. First consideration given to applications received by October 15, 1986. Equal Opportunity Employer

10000000000000000000000000000000000000000000000000000000000

\section{DEAN AND UNIVERSITY LIBRARIAN}

\section{University of Cincinnati}

The University of Cincinnati invites nominations and applications for the position of Dean and University Librarian. The University Librarian reports to the Senior Vice President and Provost and is the chief academic and executive officer for the central and branch libraries. He or she will develop and administer policies and procedures to provide optimum library support for teaching and research, direct the library's planning and budgeting activities, provide leadership in the implementation of an automated system, and represent the University Libraries to all university and community constituencies and to the research library community.

The University Libraries include a central library facility and nine college and departmental libraries. The Libraries employ 165 staff members (33 librarians and 132 support staff). Implementation of an automated library system is in progress. The University of Cincinnati is a charter member of the Association of Research Libraries (ARL) and maintains memberships in the Center for Research Libraries (CRL), the Online Computer Library Center (OCLC), and the Greater Cincinnati Library Consortium (GCLC). The Dean and University Librarian is a member of the Deans' Council and the Graduate Council.

The University of Cincinnati, which traces its origins to 1819, was for many years the second oldest and second largest municipal university in the country. It is now a member of the State of Ohio university system and is one of only two universities in the system which have been designated by the Ohio Board of Regents as comprehensive doctoral granting institutions. The University of Cincinnati is a leading participant in Ohio's Academic Excellence Program which provides enhanced funding to selected academic units. Its enrollment now exceeds 30,000 including over 5,000 graduate students.

Qualifications: The successful candidate must have a Masters in Library Science from an ALA-accredited institution. A Ph.D. is highly desirable. In addition, he or she must have (1) demonstrated leadership abilities; (2) at least five years successful administrative experience; (3) knowledge of current trends in research libraries and library automation; (4) a record of both professional and scholarly achievement; and (5) the ability to communicate effectively. The position is a twelve-month administrative appointment. The salary is open and competitive. The minimum salary is $\$ 60,000$.

Nominations and applications will be reviewed beginning October 30, 1986; however, they will be received until an appointment is made. Women and minorities are encouraged to apply. Nominations and applications with resume with list of references should be sent to:

\section{Dean Robert J. Werner \\ Chairman, Dean and University Librarian Search Committee \\ 640 Langsam Library \\ Cincinnati, $\mathrm{OH}$ 45221-0033}


REFERENCE LIBRARIAN, BUSINESS EMPHASIS. Responsibilities include bibliographic instruction, collection development, and liaison with business, economics, computer science, and math departments; online searching; general reference duties; supervision of interlibrary loan; and participation in library policy formulation. Requirements: MLS from ALA-accredited program, 2 years' professional reference experience, experience with business reference sources, bibliographic instruction, and online searching. Desirable: supervisory experience, interlibrary loan experience, or corporate reference service experience. Candidates must submit a letter detailing what they can bring to the position and a resume including the names and phone numbers of 3 individuals able to supply detailed references. Position available January 2, 1987. Minimum salary: $\$ 22,500$ for a 12-month/year appointment. Optional tenure track; benefits include TIAA/CREF and 22 days' vacation. Send all applications to: Christina Martinez, Head of User Services, Library, University of Colorado at Colorado Springs, P.O.B. 7150, Colorado Springs, CO 80933. Applications must be postmarked by October 15,1986 . The University of Colorado is an AA, EOE employer.

REFERENCE LIBRARIAN. DePauw University is seeking an innovative, service-oriented librarian to provide reference services as part of a public services department in an undergraduate liberal arts college library. Duties will be a combination of reference desk service, bibliographic instruction, online searching, and liaison work with selected departments in collection development. The library is currently undergoing a complete renovation and will be shortly developing its plans for automation. Qualifications include an ALAaccredited MLS degree and some reference experience. A second master's degree and experience with online searching, collection development or bibliographic instruction desirable. Salary dependent on qualifications; $\$ 17,000$ minimum. Letter of application should include candidate's views on library service in an undergraduate liberal arts college. Send letter of application, resume, and 3 let ters of reference to: Jana Bradley, Director of Libraries, DePauw University, Box 137, Greencastle, IN 46135. Review of applications will begin September 30, 1986. Affirmative action, equal opportunity employer.

REFERENCE LIBRARIAN. Position available for Reference Libraran with the Collin County Community College District. Position will involve shared responsibilities for collection development, development for OCLC system, reference services and technical services. Requires an MLS from an ALA-accredited institution, with expertise in OCLC and technical services a plus. If interested, please call or write: Collin County Community College, Personnel Department 2200 West University, McKinney, TX 75069; (214) 548-9971, ext. 307. Equal opportunity employer.

REFERENCE LIBRARIANS (Two positions available). Sterling Me morial Library, Yale University Library. (Minimum Rank: Librarian I) Responsibilities: Provide reference desk assistance, bibliographic instruction, and computerized database searching. Participate in collection development and planning activities. The department, the central reference location on campus, serves all levels of users with special focus in the humanities and social sciences, and is in an exciting period of development as it seeks to expand its role in meeting the information needs of the Yale community. Qualifications: ALAaccredited MLS. Reading knowledge of two foreign languages. Familiarity with online database searching. Interest in bibliographic instruction. Effective oral and written communication and strong analytical skills. Ability to work cooperatively in a demanding and rapidly changing environment. Additional graduate work desirable. Salary from $\$ 22,500$ dependent on qualifications. Benefits include 22 days vacation; 16 holiday, recess and personal days; comprehensive health care; and relocation assistance. To be assured of consideration, please send letter of application, resume, and names of 3 references to: Linda Green, Assistant Personnel Librarian, Yale University Library, P.0. Box 1603A Yale Station, New Haven, CT 06520. Application deadline: September 30, 1986. An EEO/AA employer.

\section{DIRECTOR}

\section{Leon S. McGoogan Library of Medicine and Midcontinental Regional Medical Library Program, University of Nebraska Medical Center}

The University of Nebraska Medical Center invites applications for the position of Director, Leon S. McGoogan Library of Medicine and Midcontinental Regional Medical Library Program (MCRMLP). The Library is a major academic health sciences library serving the patient care, education, and research needs of the Medical Center which includes the Colleges of Medicine, Nursing, Pharmacy, and Dentistry; School of Allied Health; Graduate Studies Program; University Hospital; and several research and service institutes. In addition, the Library serves as the Headquarters for the MCRMLP (Region 4) coordinating regional medical library services for a six-state region under contract with the National Library of Medicine. The Director provides leadership for and has overall administrative responsibility for a library with an integrated library system, a collection of over 215,000 volumes and 2,300 current subscriptions, and a budget of over $\$ 1.6$ million for the library and the MCRMLP. The combined staff numbers 49 FTE of which 17.5 are Professional. The Director reports to the Vice Chancellor for Academic Affairs.

The successful applicant will be experienced in library administration in an automated environment, familiar with current trends in academic information management, be capable of planning and implementing comprehensive information services in a comprehensive academic health sciences center, and be active in scholarly and professional activities. In addition, an ALA-accredited Master's degree and 5-7 years of progressively responsible experience required; advanced graduate study is desirable; capability of working with academic, library, and governing groups and individuals; and administrative experience in program planning, personnel management, and budgeting will be expected.

This is a specific term faculty appointment leading to tenure with appropriate rank, privileges, responsibilities, and fringe benefits. Salary from $\$ 54,000$, commensurate with experience and qualifications. Deadline for applications is October 31, 1986. Send letter of application, curriculum vitae, and names of 3-5 references to: William Berndt, Vice Chancellor for Academic Affairs, University of Nebraska Medical Center, 42nd and Dewey Ave., Omaha, NE 68105-1065. 
ROMANCE LANGUAGES LIBRARIAN. The University of California, Irvine invites applications for the position of Romance Lan guages Librarian in the Main Library. This is an entry-level appointment at the Assistant Librarian rank at a salary of $\$ 24,012$. Upward adjustments may be made for appropriate advanced degrees. Applications received by October 15, 1986, will receive first consideration, but applications will be accepted until the position is filled. Responsibilities: The incumbent serves as a reference librarian reporting to the Head of Reference and as a bibliographer reporting to the Head of Collection Development. The reporting line is through the Reference Department. Reference librarians in the Main Library share responsibility for general and specialized reference service (including evening and weekend assignments). These responsibilities include reference desk assistance to library users in conceptual, in tellectual, and bibliographic access to information; database search ing; and bibliographic instruction. The incumbent functions as a liaison with the School of Humanities, and specifically with the Department of Spanish and Portuguese, and the Department of French and Italian. As a bibliographer, the incumbent shares with the Head of Collection Development and other bibliographers the responsibility for development and management of all library collections, with special responsibility for developing and maintaining materials to support the research and instructional needs of faculty and students in the School of Humanities, and specifically in the Department of Spanish and Portuguese, and the Department of French and Italian. Additionally, the position is responsible for Latin American studies. Qualifications: Required: ALA-accredited MLS degree; de gree in Spanish or French or commensurate experience, including good reading knowledge of Spanish and French. Demonstrated commitment to public service; excellent oral and written communication skills. Ability to work effectively, independently, and cooperatively with all elements of the academic community. Desirable: Additional graduate degree in Spanish or French. Good reading knowledge of Portuguese and Italian. Experience in collection devel opment, bibliographic instruction, and database searching. To apply: Send application letter with 1) a complete statement of qualifications; 2) resume of education and relevant experience; and 3) the names, addresses, and telephone numbers of three references. Letters should be addressed to: Karen Nassaur, Library Personnel Of fice, University of California, Irvine, P.0. Box 19557, Irvine, CA 92713. Telephone: (714) 856-5408. An affirmative action, equal opportunity employer
SCIENCE LIBRARIAN, Assistant Professor (tenure-leading). Sciences \& Technology Department, starting January 1, 1987. Liaison responsibilities, including collection development, library instruction, online literature searching, and referral reference with the faculty and students in selected departments of the Institute of Agriculture and Natural Resources. Information desk responsibilities. Required: MLS from a program accredited by the American Library Association; undergraduate or advanced degree in a pure or applied science; and ability to relate to patrons and staff. Preferred: Experience and training with online literature searching. $\$ 17,500$ minimum for a 12-month contract. Salary may be higher depending upon the qualifications of the successful applicant. Apply with full resume plus names and current addresses/telephone numbers of three references by October 15, 1986, to: Kent Hendrickson, Dean of Libraries, 106 Love Library, University of Nebraska-Lincoln, Lincoln, $\mathrm{Ne}$ braska 68588-0410. Affirmative Action, Equal Opportunity Employer.

SCIENCE REFERENCE LIBRARIAN, Science and Engineering Library, University of California, San Diego. Starting date: January 1 1987. Rank: Assistant Librarian, Salary: $\$ 24,012-\$ 30,720$ or Associate Librarian, Salary: $\$ 29,340-\$ 42,264$. The Science and Engineering Library's 144,000 volumes and 2,300 active serials comprise a collection that supports instruction and research in the fields of chemistry, physics, mathematics, computer science, and the programs in the Division of Engineering. The Science and Engineering Library staff is comprised of four librarians, an administrative assistant, seven library assistants, and approximately 4 FTE student assistants. The library's public services include reference and online search service; library instruction; circulation and class reserves; interlibrary borrowing and lending; and photocopy services. Technical services include serial acquisitions, check-in and binding. Qualifications: MLS from an ALA-accredited library school. Academic background in science or experience in science libraries; understanding of scientific research and ability to work effectively with members of academic community; experience with online literature searching and reference service; demonstrated communication skills and teaching abilities; familiarity with trends in scientific information services and automated systems. Desirable: knowledge of interlibrary loan operations; familiarity with uses of microcomputers in library applications. Will consider entry-level appointment with outstanding qualifications. Appointment at the Associate Librarian rank

\section{DIRECTOR OF LIBRARIES North Carolina State University}

North Carolina State University invites nominations and applications for the position of Director of Libraries. The University offers approximately 2,800 courses to 24,000 students and has a faculty and professional staff of more than 2,400. The Director has responsibilities for the D. H. Hill Library; four branch libraries serving the Schools of Design, Forest Resources, Textiles, Veterinary Medicine; and several departmental collections. The libraries have a staff of 165 persons who operate 21 specialized departments that contain 1,300,000 volumes, 2,000,000 microforms and 600,000 U. S. Government publications. D. H. Hill Library is an ARL Library and a member of the Triangle Research Libraries Network (TRLN).

The Director is responsible for the operation and management of the University's library system, serves on the governing board of TRLN, and reports to the Provost. Candidates should have substantial experience in management of an academic or research library, experience in administering technological innovations in library automated services, and demonstrated effective leadership abilities. An ALA-accredited library degree is required; an earned doctorate is preferred.

The position is available July 1, 1987. Minimum Salary: $\$ 55,000$. Applications and nominations should be received by October 31, 1986, accompanied by a resume and the names, addresses and telephone numbers of three references. Send applications to:

\section{William H. Simpson \\ Secretary, Nomination Committee \\ Director of Libraries \\ North Carolina State University \\ Box 7001 \\ Raleigh, NC 27695-7001}


requires well-developed reference and computerized literature searching skills, and substantial relevant experience. UCSD is an equal opportunity, affirmative action employer. Applications received or postmarked by September 30, 1986 are assured of consideration. Submit a letter of application, enclosing a resume and a list of references to: Ellen Lawson, Administrative Assistant for Academic Personnel, Library, C-075-H, University of California, San Diego, La Jolla, CA 92093.

SCIENCE SUBJECT SPECIALIST/REFERENCE LIBRARIAN. Appointment salary minimum: $\$ 18,000$. Library assignment: Reference and Instruction Department. Position description: Subject backgrounds sought (some combination of the following): Chemistry, Physics, Mathematics, Statistics, Computer Science or Forensic Science. Full-time appointment available immediately. As subject specialist, serves as the liaison to assigned departments and programs. Provides specialized research support and consultation services and assumes collection development responsibilities for assigned subjects. As member of Reference and Instruction Department, participates in providing general reference services to faculty, graduate and undergraduate students, and staff of the University in all academic and professional fields, except law and medicine. Reference librarians participate in direct reference assistance; bibliographic instruction; preparation of bibliographies, guides and other instruction aids; online computer searching; and library-wide committee work and planning. Reference responsibilities include regular evening duties and weekend duties on a rotational basis. Reports to the Head of the Reference and Instruction Department. Qualifications: ALA-accredited Masters degree and ability to work effectively with the public and co-workers are required. Appropriate subject background should be demonstrated through academic de grees, formal coursework, or other substantive experience. Experience or coursework in computer searching or bibliographic instruc tion highly desirable. Minimum salary: $\$ 18,000$. Rank and salary negotiable based on experience and qualifications. Closing date for application is October 15, 1986. Please send current resume and names of three references to: Mattie Rogers-Allen, Executive Coordinator, Gelman Library, The George Washington University, Washington, DC 20052. GWU is an equal opportunity, affirmative action employer

SERIALS CATALOGER. Catalogs serials in all subject areas, formats, and languages according to AACR2, OCLC, and LC standards; performs authority work; upgrades and enhances bibliographic information in GEAC MARC database. Reports to Head Serials Cataloger. The Serials Department, comprised of 3 professional librarians and 11 administrative and support staff, is responsible for procuring, receiving, and cataloging serials. Library faculty must meet university requirements for promotion and tenure. Re quired qualifications: ALA-accredited MLS; knowledge of AACR2 LC classification and subject headings and familiarity with a bibliographic utility, preferably OCLC; ability to work with foreign language materials; good communications skills. Previous serials cataloging experience in an academic library preferred. Tenure-track position. 24 days annual leave. Tuition remission. Group health in surance. TIAA/CREF or state retirement plan with non-refundable contributions paid by the university. No state income tax. Rank and salary dependent upon education and experience. Instructor: $\$ 19,000$ minimum; Assistant Professor: $\$ 23,000$ minimum. Send letter of application, current resume and names, addresses, and telephone numbers of 3 recent references by October 15, 1986, to: Jill Keally, Personnel Librarian, The University of Tennessee Library, Knoxville, TN 37996-1000. UTK is an EEO, Affirmative Action, Title IX, Section 504 employer.

SERIALS CATALOGER. The Health Sciences Library at the University of North Carolina at Chapel Hill invites applications for Serials Cataloger. This position catalogs serials on the OCLC online system, assignıng LC or NLM classification and $\mathrm{MeSH}$ headings, and investigates and helps resolve problems or inconsistencies in serials cataloging. This person reports to the Head of Cataloging Services and works closely with the Serials Librarian to maintain serials records and provide automated serials control. ALA-accredited master's re quired. Experience in the following highly desirable: serials cataloging, OCLC, health sciences cataloging. Qualities sought include good problem solving skills, flexibility, initiative, excellent interpersonal and communication skills, and a commitment to serving the information needs of health professionals. Salary based on experience: for example, minimum $\$ 18,000$; base salary with 3 years relevant experience $\$ 21,000$. The Health Sciences Library has a professional staff of 24; it serves 5 professional schools and North Carolina Memorial Hospital. Send letter of application, curriculum viae and names of 3 references to: Carol Jenkins, Director, Health Sciences Library $223 \mathrm{H}$, University of North Carolina at Chapel Hill Chapel Hill, NC 27514. Deadline for applications September 26 1986. An Affirmative Action, Equal Opportunity Employer

SERIALS CATALOGER, University of Michigan. Assistant Librar ian, Serials Cataloging Section, Serials Division, Technical Services. Responsibilities include: perform original cataloging and RLIN record editing for Western European langauge serials for the University Library System in all formats and in all subject areas, using AACR2, LC classification, and LC subject headings; establish headings for monographic series and name authority records as required; catalog or recatalog serials for title changes; resolve serial problems; participate in special assignments, including NOTIS implementation, as assigned. Required: ALA-accredited MLS; knowledge of current cataloging rules and of LC classification and subject headings; work ng knowledge of two non-English Western European languages: good interpersonal and communication skills; aptitude for precision work and independent problem solving; ability to work effectively in a rapidly changing environment as a member of a professional team. Desired: Prior pre-professional or professional experience in cataloging or in serials, especially in an academic or research library; some familiarity with past cataloging rules; knowledge of MARC or MARC-S; experience with RLIN, OCLC or other automated catalog ing systems; working knowledge of an additional Western European language. Minimum salary $\$ 18,500$. Applications received by September 30, 1986, will be given first consideration. Apply to: Library Personnel Office, 404 Hatcher Graduate Library, University of Michigan, Ann Arbor, Ml 48109-1205. The University of Michigan is a nondiscriminatory, affirmative action employer

SERIALS CATALOGING SUPERVISOR (Search extended; qualifications revised). Rank: Assistant Professor or higher (renewable contract). Reports to: Head, Catalog Department. Duties and re sponsibilities: Supervises the Serials Cataloging Section and catalogs serials using OCLC. Coordinates University of Oregon partici pation in Oregon Regional Union List of Serials. Plans the work of the unit; writes and revises routines for serial cataloging. Participates in meetings of Catalog Department Section Heads. Acts as resource person for library staff on questions concerning serials cataloging Qualifications: MLS from ALA-accredited library school. Two to three years serials cataloging experience preferred. Demonstrated experience with AACR2, MARC serials format, LC classification, LCSH, MARC formats, OCLC or other major bibliographic utility. Reading knowledge of at least one Western European language. Good writ ten and oral communication skills. Ability to work effectively with al levels of staff. Supervisory experience desirable. Salary $\$ 18,500-\$ 22,000$ plus fringe benefits; $12-$ month appointment. Position open: Immediately. Application deadline: October 1, 1986. Applications to include: Cover letter, resume and names of three refer ences. Apply to: Andrew Bonamici, Personnel Librarian, University of Oregon Library, Eugene, OR 97403-1299. An Equal Opportunity Affirmative Action Institution.

SYSTEMS LIBRARIAN. The Harvard University Library is actively involved in the development and use of large-scale computer systems, and is seeking a qualified and energetic person to join its Office for Systems Planning and Research. This position involves the full range of systems development and maintenance tasks, including analysis, systems design and specification, programming, and documentation and may include responsibility for a major automated catalog system. Candidates should have a library science degree or equivalent experience, familiarity with automated library applications, demonstrated aptitude for computer programming, and excellent written and verbal communication skills. Familiarity with MARC formats and IBM operating systems is strongly perferred. Competence in PL/1 or BAL, experience in research libraries, and familiarity with CICS and VSAM is desirable. Open September 1, 1986. Librarian I or II depending on qualifications. Competitive salary with minimum of $\$ 18,800$ for Librarian I and $\$ 22,387$ for Librarian II. Good benefits package. Resumes to: Karen McFarlan, University Personnel Librarian, Harvard University, Wadsworth House, Cambridge MA 02138. An equal opportunity, affirmative action employer.

TECHNICAL SERVICES LIBRARIAN, Kirksville College of Osteopathic Medicine, Kirksville, Missouri. Responsible for original and copy cataloging of all materials, OCLC/LC; planning for automation maintenance of catalog and databases; supervision of RECON proj 
ect; supervision of serials and acquisitions; reference work on rotation. Requirements: ALA-accredited MLS with 3 years cataloging experience (preferably in a health sciences library), OCLC, LC and RECON experience, knowledge of serials and acquisition proce dures. Preferred qualifications: Good oral and written communication skills and experience in microcomputer applications. Salary $\$ 18,000$ for 12 months, plus fringe benefits. Send letter of applica tion, names of three references and resume to: Lawrence W. Onsager, Lıbrary Director, Kirksville College of Osteopathic Medicine 800 W. Jefferson, Kirksville, MO 63501. Deadline for applications is October 15, 1986. An equal opportunity, affirmative action employer.

UNIVERSITY ARCHIVIST. Appointment salary minimum $\$ 20,000$. Library assignment: Special Collections Department. Position description: Manages a university-wide archives and records management program for administrative, fiscal, legal and historical records of the university. Will direct comprehensive records survey Responsibilites incude developing and implementing policies and procedures for effective use of university archives and records. Will establish and maintain contact with all university offices and organi zations and will educate and advise on program. Directs preparation of research aids for university archives; supervises compilation of online faculty publications database; advises researchers in the use of university archives and records. Supervises at least 1 FTE support staff and students. The University Archivist reports to the Head, Department of Special Collections. As with all professionals at Gelman Library, the University Archivist will serve as a subject specialist in assigned academic disciplines. Qualifications: Required: Formal training in archives; minimum two years archival experience in an academic or research library; strong interpersonal and communication skills; demonstrated administrative and organizational ability; supervisory experience and knowledge of preservation techniques and research use of archival collections; ability to interact effectively with administrators, faculty and staff. Preferred: ALA-accredited MLS; advanced degree in social sciences or humanities; knowledge of microcomputer applications to archival materials processing; experience in teaching; a record of professional involvement. Salary: from $\$ 20,000$. Salary is dependent upon background and experience. Closing date for application is October 15, 1986. Please send current resume and names of three references to: Mattie Rogers-Allen, Executive Coordinator, Gelman Library, The George Washington University, Washington, DC 20052. GWU is an equal opportunity, affirmative action employer.

ASSISTANT TO THE LILLY LIBRARIAN. Assistant or Associate Librarian, Indiana University, Bloomington. Responsible for scheduling and overseeing museum operations of Lilly Library, including exhibitions, special programs, tours for visitors; for planning and overseeing production of Lilly Library publications--catalogues, brochures, periodicals, media releases. Assists in activities of the Friends of the Lilly Library; supervises one full-time support staff member and six to eight part-time receptionists. Qualifications: Master's degree in library science from ALA-accredited school; ability to work on own initiative; to enlist cooperation among a wide constituency within and beyond the University; to meet responsibilities and requirements of tenure-track appointment. Desirable: subject and foreign language expertise in some areas (e.g., history, literature, theology, law, science, music) in which the Lilly Library has strong collections; training and experience in rare book bibliography; experience in writing and editing, experience with museum or library exhibitions. Salary dependent upon qualifications and experience. Minimum: Assistant Librarian \$19,500, Associate Librarian \$24,000. Benefits include vacation of 22 working days, Blue Cross/Blue Shield, major medical, group life insurance, TIAA/CREF retirement/annuity plan, eligibility for sabbatical and research leaves. To apply send letter of application and names and addresses of four references to: Anne Rimmer, Personnel officer, Indiana University Libraries, Bloomington, IN 47405. Telephone: (812) 335-3403. Available date: January 1, 1987. Closing date: No earlier than September 30, 1986. EEO/AAE.

BIOMEDICAL LIBRARIAN, Bio-Agricultural Library. Major responsibilities for this position include: 1) Biomedical reference assistance, online searching, and end-user search training; 2) general science reference desk assignment and database searching; 3) Biomedical collection development; 4) 1ibrary instruction; and 5) consultation on information retrieval and management. Qualifications: Required: Graduate Library degree or equivalent. Experience in a science or biomedical library in an academic institution or a scientific business research environment, or substantial coursework in health or life sciences or medical librarianship. Online search experience with MEDLARS, and DIALOG or BRS. Familiarity with microcomputers and software for information retrieval and management. Other desirable qualifications include good communication skills and experience with offering end-user search training. Salary range: $\$ 24,012-\$ 36,828$. Rank: Assistant or Associate Librarian. Send letter of application, resume, and list of three professional references to: James C. Thompson, University Librarian, University of California, Riverside, P.0. Box 5900, Riverside, CA 92517. Deadline for application is 
October 31, 1986. The University of California is an affirmative action, equal opportunity employer.

CATALOG LIBRARIAN (Two positions available). Duties include original cataloging and editing OCLC copy in MARC formats (monographs and audiovisuals) for an online catalog. MLS from ALA-accredited school required. Two to three years experience preferred, especially with working knowledge of LC classification and subject headings, AACR2 and OCLC. Knowledge of at least one European language highly desirable. Twelve-month appointment. Faculty rank and salary commensurate with qualifications; $\$ 20,000$ minimum; TIAA/CREF and State mandated benefits. Send resume and names of three references by October 15, 1986, to: Raymond A. Frankle, Director, J. Murrey Atkins Library, UNCC, Charlotte, NC 28223. The University of North Carolina at Charlotte is an Equal Opportunity, Affirmative Action employer. Women and minorities are encouraged to apply.

COORDINATOR OF CONTRIBUTED CATALOGING. Position to be filled between October 20 and November 18, 1986. Under the direction of the Head of the Cataloging Department oversees the quality of work performed by paraprofessionals engaged in editing OCLC contributed cataloging and CIP data for rush items. Trains, revises, and advises paraprofessionals who revise or supply LC classification, LC subject headings, descriptive cataloging, and OCLC/MARC tags and subfield and fixed field codes. Also oversees name, series, and subject authority work performed by paraprofessionals. Performs original cataloging of monographs and, as needed, participates in retrospective conversion. Participates with colleagues in the formation of departmental policies and procedures. ALA-accredited MLS required. Minimum two years professional experience in a cataloging department, preferably in an academic library utilizing ocLC or other online cataloging system. Supervisory experience desired. A second master's degree is highly desirable and is expected for tenure. Salary range $\$ 21,000$ to $\$ 26,000$ for twelve months, depending on experience and qualifications. Tenure eligible. TIAA/CREF, Blue Cross/Blue Shield, or HMO. Twenty-two days annual leave. Send letter of application, resume, and the names of three current professional references by october 10, 1986, to: Alexander T. Birrell, Head, Cataloging Department, Ablah Library, Box 68, The Wichita State University, Wichita, KS 67208. Finalists will be invited for an expense-paid interview. The Wichita State University is an urban institution with an enrollment of 17,000. Librarians at The Wichita State University have faculty rank, privileges, and responsibilities. The Wichita State University is an affirmative action, equal opportunity employer.

CURRICULUM CENTER LIBRARIAN. Responsible for all aspects of the administration, operation, and development of the Curriculum and Instructional Materials Center (CIMC). Resources in the CIMC include print, non-print, and microcomputer materials. As a member of the Library's Reference Unit, there will be some general reference desk duties including some night and weekend work; bibliographic instruction and computerized database searching in related disciplines will also be required. This position will be expected to work closely, cooperatively, and in coordination with the Education Reference Librarian and to maintain liaison relationships with appropriate on and off campus agencies and individuals. Qualifications: ALA-accredited Master's degree. Second advanced degree in Education or a related discipline, or substantial experience in Education, is preferred. Two years experience working with K-12 curriculum materials either in a library or classroom setting is preferred. Knowledge of $\mathrm{K}-12$ microcomputing resources is highly desirable. Reference and computerized database searching is preferred. Benefits: Twelve-month appointment, tenure track position, rank commensurate with experience. State mandated benefits. Salary: $\$ 20,000$ (minimum). Send 
resume and names of three references by October 15, 1986, to: Raymond A. Frankle, Director, J. Murrey Atkins Library, UNCC, Charlotte, NC 28223. The University of North Carolina at Charlotte is an Equal Opportunity, Affirmative Action employer. Women and minorities are encouraged to apply.

ENGINEERING LIBRARIAN. The University of Minnesota Duluth Library \& Learning Resources Service is seeking an Engineering Librarian for its Science Reference Department. Responsible for reference, bibliographic instruction, and online database service to the College of Science and Engineering and other scientific units of the university. Participate in general reference desk coverage, perform collection development and bibliographer duties in Engineering and related sciences, special projects and occasional administrative functions as assigned. Qualifications: Require a MLS from an ALA-accredited library school, educational background in engineering sciences, formal training and experience in online bibliographic searching, and 1 year experience in academic engineering or industrial technical library. Demonstrated ability in interpersonal communication and public relations desirable. Salary: $\$ 24,500$. Resume and three references to: Joanne Line, Assistant Administrator, Library and Learning Resources Service, University of Minnesota, 10 University Drive, Duluth, MN 55812-2946 by October 31, 1986 . The University of Minnesota is an equal opportunity educator and employer, and specifically encourages applications from women and minorities.

LIBRARIAN, The New-York Historical Society. The New-York Historical Society invites applications and nominations for the position of Librarian. The New-York Historical Society is an independent cultural institution which operates a research library and museum. Responsibilities: to provide bold and imaginative leadership in enhancing a major research library utilizing traditional as well as innovative technologies; participate in planning and evaluating the policies and procedures which support the Society's objectives and programs; maintain close communication between the library staff, Society staff, and the professional world; guide the expansion of present library holdings and facilities; implement further appropriate information technologies; assist in the solicitation of grants, benefactors, and prospective gifts; build a broader community interest and support for the library; plan and direct the library budget; administer the library process. The Librarian directly supervises the Assistant Librarian for Reference Services, the Assistant Librarian for Technical Services, the Collections Development Librarian, the Curator of Maps, and the Conservator for Library Materials. Reporting to the Director of the Society, supervises a large research library relating to the history of New York City, New York State and the United States. The library contains more than 600,000 volumes, 2 million manuscript items and a staff of over 40. The individual appointed will be responsible for the overall management of the library with primary emphasis on collection development, technology planning, reference and bibliographic services and staff development. Requires: management of budget; experience with RLIN and OCLC systems; Ph.D. preferred in a subject field related to the Society's library interests; MLS from an ALA-accredited library school, or equivalent professional training and experience; ability to communicate effectively orally and in writing; extensive demonstrated administrative and supervisory experience in a research library; knowledge of current trends and applications of library information technologies; proven leadership and motivational abilities; evidence of continuous growth through scholarly publication and active participation in the individual discipline and/or profession. Salary range mid 40's, dependent on qualifications and experience. Group life, major medical, disability insurance plans are in effect as is a TIAA/CREF retirement benefits program. Application deadline September 30, 1986. Send resume and three professional references to: 
Director, The New-York Historical Society, 170 Central Park West, New York, NY 10024. An Equal Opportunity, Affirmative Action Employer.

MANUSCRIPT CATALOGER. The Rosenbach Museum \& Library seeks an experienced cataloger for its collections of 16 th- to 20 th-century American \& British manuscripts. Records will be created using RLIN formats. Item-level descriptions, with subject analytics, will be required in most instances. Cataloger will have supervisory responsibility for two assistants. This is a 3-year, grant-funded position. Funding not yet finalized, but anticipated to begin October 1986. Qualifications: M.A. in Library Science or equivalent. 1-2 years' experience with MARC cataloging of manuscripts archives or rare books and experience with subject cataloging preferred. Salary range $\$ 16,000-\$ 18,000$ plus benefits. Application deadline: October 1, 1986. Send resume and names of 3 references to: Ellen S. Dunlap, Director, Rosenbach Museum \& Library, 2010 DeLancey Place, Philadelphia, PA 19103.

PROGRAM OFFICER, Library Administration and Management Association, a Division of the American Library Association. Responsible for implementation of LAMA programming (regional institutes, preconferences and annual conference programs). Other duties include assistance with LAMA's publishing program, inquiries from members and others, and support for work of the LAMA Board of Directors, Sections, Committees and Discussion Groups. Reports to LAMA Executive Director. Qualifications: MLS degree from ALA-accredited school. Competence in planning and implementation of CE offerings. Publishing experience desirable. General subject knowledge in LAMA's areas of concern. Salary: $\$ 24,283-\$ 36,425$. Letters of application and resume must be received at ALA by September 30, 1986. Send materials to: Personnel office, American Library Association, $50 \mathrm{E}$. Huron St., Chicago, IL 60611. ALA is an Equal Opportunity, Affirmative Action Employer.

SCIENCE LIBRARIAN. The University of Minnesota Duluth Library and Learning Resources Service is seeking a Reference Librarian for its Science Reference Department. Responsible for reference, bibliographic instruction, and online database service to the College of Science and Engineering and other scientific units of the University. Participate in general reference desk coverage, perform designated subject-specialty collection development and bibliographer duties, special projects and occasional administrative functions as assigned. Require an MLS from an ALA-accredited library school, educational background in chemistry, mathematical sciences, or physics and formal training and experience in online bibliographic searching. Demonstrated ability in interpersonal communication and public relations desirable. Salary: $\$ 23,500$. Resume and three references to: Joanne Line, Assistant Administrator, Library and Learning Resources Service, University of Minnesota, 10 University Drive, Duluth, MN 55812-2946 by October 31, 1986. The University of Minnesota is an equal opportunity employer and specifically invites and encourages applications from women and minorities.

SERIALS LIBRARIAN. Open August 2, 1986. Supervises serials section, needs knowledge of computers, OCLC, serials cataloging. Also selects materials in modern languages and literatures. ALA-accredited MLS required, plus appropriate subject competence. Faculty status and equivalent rank. 5-year probationary period of annual appointments; second Master's degree or equivalent required for tenure. Salary range $\$ 15,717-\$ 23,138$, depending upon education and experience. Library of 633,069 volumes, staff of 63 (22 librarians). Budget of $\$ 2,546,131$ ( $\$ 709,000$ for materials). Enrollment of 11,000. Send letter of application, resume, references by October 17, 1986, to: Jessica A. Marshall, Head of Acquisitions, University of Northern Iowa, Donald 0. Rod Library, Cedar Falls, Iowa 50613. An affirmative action, equal opportunity employer. 


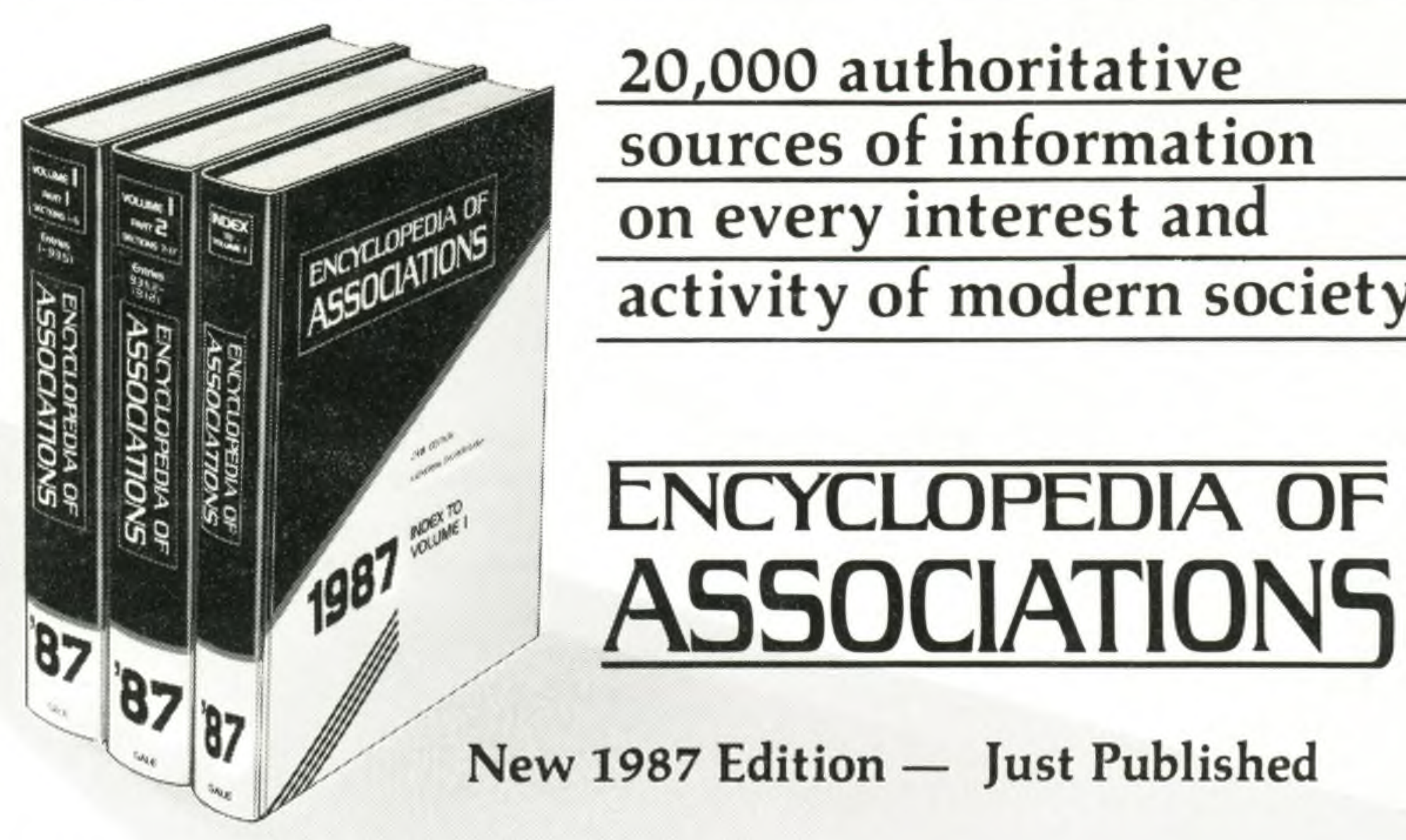

Edited by Katherine Gruber. 2,500 pages in 3 books.

$\$ 220.00 /$ set. Extra copies of the Index available for $\$ 35.00$. Available at Gale's 5\% Standing Order Discount.

The new, revised edition of Encyclopedia of Associations can help you answer more questions-with greater accuracy - than any other reference tool. Here are 20,000 sources to write, phone, or visit for information on business, consumer affairs, crime prevention, entertainment, family relations, health and medicine, hobbies, real estate . . over 2,500 subjects from archaeology to nuclear issues.

\section{Easy to use}

For answers to general reference as well as productive browsing, EA-1987 is arranged in 3 books. Books 1 and 2 are divided into 17 major subject sections. Within each of the 17 sections, entries are arranged by specific subjects. This facilitates productive browsing for contacts and ideas.

\section{Separate Index}

Book 3 of EA is an all-in-one Alphabetical and Key Word Index. All organizations as well as their committees and programs are listed by Title and Subject Key Word. Cross references to over 6,000 research centers, consulting organizations, and information centers listed in other Gale directories are also included.

\section{For fast service-}

Order Tollfree: 800-223-Gale

Send a check with your order and receive a 5\% discount. All books are available on 60-day approval.

Customers outside the U.S. and Canada add 10\%.

EA is unequaled for many projects such as:

- General Reference

- Educational Projects

- Student Research for special reports, term papers, and honor programs

- Vocational Guidance Literature from professional societies

- Market Research, Industrial Studies, New Product Development

- Teaching-Aid Materials: literature, specimens, pictures, flash cards, slides, movies, speakers

- Acquiring Specialized Publications

- Public Relations Campaigns

- Mailing Lists and Sources

- Locating or Filling Jobs for Specialists

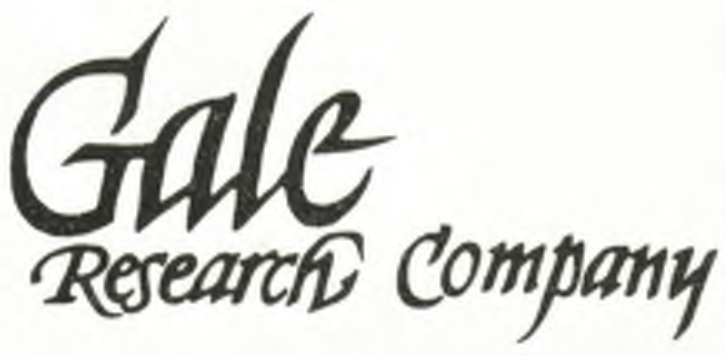

